\title{
Ch. I. Of Philip, the Father of Alexander the Great, King of Macedon
}

\section{Ch. II. Of Alexander the Great}

\$I. A briefe rehearsall of Alexanders doings, before hee inuaded Asia.

Alexander, afterward called the Great, succeeded vnto Philip his Father; being a Prince no lesse valiant by Nature, than by Education, well instructed, and inriched in all sorts of Learning and good Arts. He began his raigne ouer the Macedonians foure hundred and seuenteene years after Rome built, and after his owne birth twentie yeares. The strange dreames of Philip his Father, and that one of the Gods, in the shape of a Snake, begat him on Olympias his Mother, I omit as foolish tales; but that the Temple of Diana (a worke the most magnificent of the World) was burnt vpon the day of his birth, and that so strange an accident was accompanied with the newes of three seuerall victories obtained by the Macedonians, it was very remarkeable, and might with the reason of those times be interpreted for ominous, and foreshewing the great thinges by Alexander afterward performed. Vpon the change of the King, the Neighbour-Nations, whom Philip had opprest, beganne to consult about the recouerie of their former libertie, and to aduenture it by force of Armes. Alexanders yong-yeares gaue them hope of preuailing, and his suspected seueritie increased courage in those, who could better resolue to die, than to liue slauishly. But Alexander gaue no time to those swelling humours, which might speedily haue endangered the health of his estate. For after reuenge taken vpon the Conspirators against his Father, whom he slew vpon his Tombe; and the celebration of his Funeralls, hee first fastened vnto him his owne 
Nation, by freeing them from all exactions, and bodily slauerie, other than their seruice in his warres; and vsed such Kingly austeritie towards those that contemned his yong yeares, and such clemencie to the rest that perswaded themselues of the crueltie of his disposition, as all affections being pacified at home, $\mathrm{He}$ made a present journey into Peloponnesus, and so well exercised his spirits among them, as by the Counsell of the States of Greece, he was according to the great desire of his heart, elected Captaine-Generall against the Persians, vpon which warre Philip his Father had not only resolued, (who had obtained the same title of Generall Commander) but had transported vnder the leading of Parmenio, and Attalus, a part of his Armie, to recouer some places on Asia-side, for the safe descent of the rest.

This enterprise against the Persian occupied all Alexanders affections; those faire markes of riches, Honour, and large Dominion, hee now shot at both sleeping and waking: all other thoughts and imaginations were either grieuous or hatefull. But a contrarie winde ariseth; for hee receiueth aduertisement that the Athenians, Thebans, and Lacedomonians, had vnited themselues against him, and, by assistance from the Persian, hoped for the recouerie of their former freedome. Hereto they were perswaded by Demosthenes, himselfe being thereto perswaded by the gold of Persia; the deuise he vsed was more subtile than profitable, for he caused it to be bruted that Alexander was slaine in a battaile against the Triballes, and brought into the assembly a Companion whom hee had corrupted to affirme, That himselfe was present and wounded in the battaile. There is indeede a certaine Doctrine of Policie (as Policie is now a-daies defined by falshood and knauerie) that deuised rumours and lies, if they serue the turne, but for a day or two, are greatly auaileable. It is true that common people are sometime mockt by them, as Souldiers are by false alarums in the Warres; but in all that I haue obserued, I haue found the successe as ridiculous as the inuention. For as those that finde themselues at one time abused by such like brutes, doe at other times neglect their duties, when they are vpon true reports, and in occasions perilous, summoned to assemble; 
so doe all men in generall condemne the Venters of such trumperie, and for them feare vpon necessarie occasions to entertaine the truth it selfe. This labour vnlooked for, and losse of time, was not only very grieuous to Alexander, but by turning his sword from the ignoble and effeminate Persians, against which he had directed it, towards the manly and famous Grecians, of whose assistance he thought himselfe assured, his present vndertaking was greatly disordered. But he that cannot indure to striue against the winde, shall hardly attaine the Port which hee purposeth to recouer: and it no lesse becommeth the worthiest men to oppose misfortunes, than it doth the weakest children to bewaile them.

He therefore made such expedition towards these Reuolters, as that himselfe, with the Armie that followed him, brought them the first newes of his preparation. Hereupon all stagger, and the Athenians, as they were the first that moued, so were they the first that fainted, seeking by their Embassadours to pacifie the King, and to be receiued againe into his grace. Alexander was not long in resoluing; for the Persians perswaded him to pardon the Grecians. Wise men are not easily drawne from great purposes by such occasions as may easily be taken off, neither hath any King euer brought to effect any great affaire, who hath intangled himselfe in many enterprises at once, not tending to one and the same certaine end.

And hauing now quieted his borderers towards the South, he resolued to assure those Nations which lay on the Northside of Macedon, to wit, the Thracians, Triballes, Peones, Getes, Agrians, and other saluage people, which had greatly vexed with incursions, not only other of his Predecessours, but euen Philip his Father: with all which after diuers ouerthrowes giuen them, hee made peace, or else brought them into subjection. Notwithstanding this good successe he could not yet find the way out of Europe. There is nothing more naturall to man than libertie; the Greekes had enjoyed it ouer-long, and lost it too late to forget it; they therefore shake off the yoke once againe. The Thebans, who had in their Citadell a Garrison of a thousand Macedons, attempt to force it; Alexander hasteth to their succour, and 
presents himselfe with thirtie thousand foot, all old Souldiers, and three thousand horse, before the Citie, and gaue the Inhabitants some daies to resolue, being euen heart-sicke with the desire of passing into Asia. So vnwilling, indeede, he was to draw bloud of the Grecians, by whom hee hoped to serue himselfe elsewhere, that hee offered the Thebans remission, if they would only deliuer into his hands Phonix and Prothytes, the stirrers vp of the Rebellion. But they, opposing the mounting fortune of Alexander, (which bare all resistance before it, like the breaking-in of the OceanSea) in steed of such an answere, as men besieged and abandoned should haue made, demanded Philotas and Antipater to bee deliuered vnto them; as if Thebes alone, then laied in the ballance of Fortune with the Kingdome of Macedon, and many other Prouinces, could either haue euened the scale or swaied it. Therefore in the end they perished in their obstinacie. For while the Thebans oppose the Armie assailant, they are charged at the back by the Macedonian Garrison, their Citie taken and razed to the ground, sixe thousand slaine, and thirtie thousand sold for slaues, at the price of four hundred and fortie talents. This the King did to the terrour of the other Gracian Cities.

Many Arguments were vsed by Cleadas one of the prisoners, to perswade Alexander to forbeare the destruction of Thebes. He praied the King to beleeue that they were rather misse-led by giuing hastie credit to false reports, than any way malicious; for being perswaded of Alexanders death, they rebelled but against his Successour. Hee also besought the King to remember, that his father Philip had his education in that Citie, yea that his Ancestor Hercules was borne therein: but all perswasions were fruitlesse; the times wherein offences are committed, doe greatly aggrauate them. Yet for the honour he bare to learning, he pardoned all of the race of $P$ indarus the Poet, and spared, and set at libertie Timoclea, the sister of Theagenes, who died in defence of the libertie of Greece against his Father Philip. This Noble-woman being taken by a Thracian, and by him rauished, hee threatned to take her life vnlesse shee would confesse her treasure, shee led the Thracian to a Well, and told him that shee had therein cast it, and when the Thracian 
stooped to looke into the Well, shee suddainly thrust him into the mouth thereof, and stoned him to death.

Now because the Athenians had receiued into their Citie so many of the Thebans, as had escaped and fled vnto them for succour, Alexander would not grant them peace, but vpon condition to deliuer into his hands both their Orators which perswaded this second reuolt, and their Captaines; yet in the end it being a torment vnto him to retard the enterprise of Persia, he was content that the Orators should remaine, and accepted of the banishment of the Captaines, wherein he was exceeding ill aduised, had not his fortune, or rather the prouidence of God, made all the resistance against him vnprofitable: for these good Leaders of the Gracians betooke themselues to the seruice of the Persian, whom after a few daies he inuadeth.

\section{\$2. How Alexander passing into Asia, fought with the Persians upon the Riuer of Granicus.}

When all was now quieted at home, Alexander, committing to the trust of Antipater both Greece and Macedon, in the first of the Spring did passe the Hellespont, and being readie to disimbarke, hee threw a Dart towards the Asian shore, as a token of defiance, commanding his Souldiers not to make any wast in their owne Territorie, or to burne, or deface those buildings which themselues were presently, and in the future to possesse. He landed his Armie, consisting of two and thirtie thousand foot, and fiue thousand horse, all old Souldiers, neare vnto Troy, where he offered a solemne sacrifice vpon Achilles Tombe, his maternall Ancestor.

But before he left his owne coast, he put to death, without any offence giuen him, all his Mother-in-lawes Kinsmen, whom Philip his Father had greatly aduanced, not sparing such of his owne as he suspected. Hee also tooke with him, many of his tributarie Princes; of whose fidelitie he doubted; thinking by vnjust crueltie to assure all things, both in the present and future. Yet the end of all fell out contrarie to the policie which his Ambition had commended vnto him, though agreeing verie well with the justice of God; for all 
that he had planted, was soone after withered, and rooted vp; those, whom he most trusted, were the most traiterous; his mother, friends, and children, fell by such another mercilesse sword as his owne, and all manner of confusion followed his dead bodie to the graue, and left him there.

When the knowledge of Alexanders landing on Asia-side was brought to Darius, he so much scorned the Armie of Macedon, and had so contemptible an opinion of Alexander himselfe, as hauing stiled him his seruant on a letter which hee wrote vnto him, reprehending his disloialtie and audacitie (for Darius intitled himselfe King of Kings, and the Kinsmand of the Gods) hee gaue order withall to his Lieutenants of the lesser Asia, that they should take Alexander a-liue, whip him with rods, and then conuey him to his presence: that they should sinke his ships, and send the Macedons taken prisoners beyond the Red-Sea, belike into Ethiopia, or some other vnhealthfull part of Affrica.

In this sort did this glorious King, confident in the glittering, but heartlesse, multitude which he commanded, dispose of the alreadie-vanquished Macedonians; But the ill destinies of men beare them to the ground, by what strong confidence soeuer armed: The great numbers which he gathered together, and brought in one heape into the field, gaue rather an exceeding aduantage to his enemies, than any discouragement at all. For besides that they were men vtterly vnacquainted with dangers, men who by the name and countenance of their King were wont to preuaile against those of lesse courage than themselues, men that tooke more care how to embroder with gold and siluer their vpper garments, as if they attended the inuasion but of the Sunnebeames, than they did to arme themselues with yron and steele against the sharpe-pikes, swords, and darts of the hardie Macedonians; I say besides all these, euen the opinion they had of their owne numbers, of which euery one in particular hoped that it would not fall to his turne to fight, filled euery of them with the care of their owne safetie, without any intent at all to hazard any thing but their owne breath, and that of their horses, in running away. The Macedonians as they came to fight, and thereby to inrich themselues with the gold and jewells of Persia, both which 
they needed, so the Persians who expected nothing in that Warre but blowes and wounds, which they needed not, obaied the King, who had power to constraine them in assembling themselues for his seruice; but their owne feares and cowardice, which in time of danger had most power ouer them, they only then obaied, when their rebellion against so seruile a passion did justly and violently require it. For saith Vegetivs: Quemadmodum bene exercitatus miles pralium cupit, ita formidat indoctus; nam sciendum est in pugnâ vsum amplius prodesse quàm vires; As the well-practised Souldier desires to come to battaile, so the raw one feares it: for we must vnderstand, that in fight it more auailes to haue beene accustomed onto the like, than only to haue rude strength. What manner of men the Persians were, Alexander discouered in the first encounter, before which time it is said, by those that writ his Storie, That it was hard to judge, whether his daring to vndertake the Conquest of an Empire so well peopled, with a handfull of men, or the successe he had, were more to be wondred at. For at the Riuer of Granick, which seuereth the Territorie of Troy from Propontis, the Persians sought to stop his passage, taking the higher ground and banck of the riuer to defend, which Alexander was forced (as it were) to clime vp vnto, and scale from the Leuell of the water; Great resistance (saith Curtius) was made by the Persians, yet in the end Alexander preuailed. But it seemes to mee, that the victorie then gotten was exceeding easie, and that the twentie thousand Persian footmen, said to be slaine, were rather kil'd in the back, in running away, than hurt in the bosomes by resisting. For had those twentie thousand foot, and two hundred and fiftie horse-men, or, after Plutarch, two thousand and fiue hundred horse-men, died with their faces towards the Macedonians, Alexander could not haue bought their liues at so small a rate, as with the losse of foure and thirtie of all sorts of his owne. And if it were also true, that Plutarch doth report, how Alexander encountred two of the Persian Commanders, Spithridates and Rhosaces; and that the Persian horse-men fought with great furie, though in the end scattered; and lastly how those Grecians in Darius his pay holding themselues in one bodie vpon a peece of ground of SWR I 2 
aduantage, did (after mercie was refused them) fight it out to the last; how doth it then resemble truth, that such resistance hauing beene made, yet of Alexanders Armie there fell but twelue Foote-men, and two and twentie Horse-men.

\$3. A digression concerning the defence of hard passages. Of things following the battaile of Granick.

The winning of this passage did greatly encourage the Macedonians, and brought such terrour vpon all those of the lesser Asia, as hee obtained all the Kingdomes thereof without a blow, some one or two Townes excepted. For in all inuasions, where the Nations inuaded haue once beene beaten vpon a great aduantage of the place, as in defence of Riuers, Streights, and Mountaines, they will soone haue perswaded themselues, that such an enemie, vpon equall termes and euen ground, can hardly be resisted. It was therefore Machiauels counsell, that he which resolueth to defend a passage, should with his ablest force oppose the Assailant. And to say truth, few Regions of any great circuit are so well fenced, that Armies, of such force as may be thought sufficient to conquer them, can be debarred all entrance, by the naturall difficultie of the waies. One passage or other is commonly left vnguarded: if all be defended, then must the forces of the Countrie be distracted, and yet lightly, some one place will be found that is defended very weakely. How often haue the Alpes giuen way to Armies, breaking into Italie? Yea, where shall we finde that euer they kept out an inuadour? Yet are they such, as (to speake briefly) afflict with all difficulties those that trauaile ouer them; but they giue no securitie to those that lie behinde them: for they are of too large extent. The Townes of Lumbardie perswaded themselues that they might enjoy their quiet, when the Warlike Nation of the Switzers had vndertaken to hinder Francis the French King from descending into the Duchie of Milan: but whilest these Patrons of Milan, whom their owne dwelling in those Mountaines had made fittest of all other for such a seruice, were busied in custodie of the Alpes; Francis appeared in Lumbardie, to 
so much the greater terrour of the Inhabitants, by how much the lesse they had expected his arriuall. What shall we say of those Mountaines, which locke vp whole Regions in such sort, as they leaue but one Gate open? The Streights, or (as they were called) the Gates of Taurus in Cilicia, and those of Thermopyle, haue seldome beene attempted, perhaps because they were thought impregnable: but how seldome (if euer) haue they been attempted in vaine? Xerxes, and long after him, the Romans, forced the entrance of Thermopyle; Cyrus the yonger, and after him Alexander, found the Gates of Cilicia wide open; how strongly soeuer they had beene locked and barred, yet were those countries open enough to a fleet that should enter on the back-side. The defence of Riuers how hard a thing it is, wee finde examples in all histories that beare good witnesse. The deepest haue many Foords; the swiftest and broadest may bee passed by Boates, in case it be found a matter of difficultie to make a Bridge. He that hath men enough to defend all the length of his owne banke, hath also enough to beate his enemie; and may therefore doe better to let him come ouer, to his losse, than by striuing in vaine to hinder the passage, as a matter tending to his owne disaduantage, fill the heads of his Souldiers with an opinion, that they are in ill case, hauing their meanes of safeguard taken from them, by the skill or valour of such as are too good for them. Certainely if a Riuer were sufficient defence against an Armie, the Isle of Mona, now called Anglesey, which is diuided from North-Wales by an arme of the Sea; had beene safe enough against the Romans, inuading it vnder conduct of Iulius Agricola. But he wanting, and not meaning to spend the time in making vessells to transport his forces, did assay the foords. Whereby hee so amazed the enemies attending for ships and such like prouision by Sea, that surely beleeuing nothing could bee hard or inuincible to men, which came so minded to Warre, they humbly intreated for peace, and yeelded the Iland. Yet the Britaines were men stout enough; the Persians verie dastards.

It was therefore wisely done of Alexander, to passe the Riuer of Granick in face of the enemie; not marching higher to seeke an easier way, nor labouring to conuey his men ouer 
it by some safer meanes. For hauing beaten them vpon their owne ground, hee did thereby cut off no lesse of their reputation, than of their strength, leauing no hope of succour to the partakers and followers of such vnable Protectors.

Soone after this victorie he recouered Sardis, Ephesus, the Cities of the Trallians and Magnesia, which were rendred vnto him. The Inhabitants of which, with the people of the Countrie, he receiued with great grace, suffering them to be gouerned by their owne lawes. For hee obserued it well; Nouum Imperium inchoantibus vtilis elementice fama; It is commodious onto such as lay the foundations of a new Soueraignetie to haue the fame of being mercifull. Hee then by Parmenio wanne Miletus, and by force mastred Halicarnassus, which, because it resisted obstinately, hee razed to the ground. From thence hee entred into Caria, where Ada the Queene, who had beene cast out of all that shee held (except the Citie of Alinda) by Darius his Lieutenants, presented her selfe vnto him, and adopted him her sonne and successor; which Alexander accepted in so gracious part as hee left the whole Kingdome to her disposing. Hee then entred into Lycia, and Pamphilia, and obtained all the Sea-coasts, and subjecting vnto him Pisidia, he directed himselfe towards Darius (who was said to be aduanced towards him with a maruailous Armie) by the way of Phrygia: For all the Prouince of Asia the lesse, bordering vpon the Sea, his first victorie laied vnder his feet.

While he gaue order for the gouernement and setling of Lycia, and Pamphilia, he sent Cleander to raise some new Companies in Peloponnesus; and marching towards the North he entred Celenas, seated on the Riuer Meander, which was abandoned vnto him, the Castle only holding out, which also after fortie daies was giuen vp: for so long time he gaue them to attend succour from Darius. From Celenas he past on through Phrygia towards the Euxine Sea, till he came to a Citie called Gordium, the Regall-seate, in former times, of King Midas. In this Citie it was that he found the Gordianknot, which when hee knew not how to vndoe, hee cut it a-sunder with his sword. For there was an ancient prophecie did promise to him that could vntie it, the Lordship of all Asia; whereupon Alexander, not respecting the manner how, 
so it were done, assumed to himselfe the fulfilling of the prophesie, by hewing it in peeces.

But before he turned from this part of Asia the lesse towards the East, hee tooke care to cleare the Sea-coast on his backe, and to thrust the Persians out of the Ilands of Lesbos, Scio, and Coos, the charge whereof he cõmitted vnto two of his Captaines, giuing them such order as he thought to be most conuenient for that seruice; and deliuering vnto them fiftie talents to defray the charge; and withall out of his first spoile gotten, he sent threescore talents more to Antipater his Lieutenant in Greece, and Macedon. From Celenas he remoued to Ancira, now called Anguori, standing on the same Riuer of Sangarius, which runneth through Gordium: there hee mustred his Armie, and then entred Paphlagonia, whose people submitted themselues vnto him, and obtained freedome of tribute: where hee left Catus Gouernour with one Regiment of Macedonians lately arriued.

Here he vnderstood of the death of Memnon, Darius Lieutenant, which heartned him greatly to passe on towards him, for of this only Captaine hee had more respect than of all the multitude by Darius assembled, and of all the Commanders hee had besides. For so much hath the spirit of some one man excelled, as it hath vndertaken and effected the alteration of the greatest States and Common-weales, the erection of Monarchies, the conquest of Kingdomes and Empires guided handfuls of men against multitudes of equall bodily strength, contriued victories beyond all hope and discourse of reason, conuerted the fearefull passions of his owne followers into magnanimitie, and the valour of his enemies into cowardize; such spirits haue beene stirred vp in sundrie Ages of the world, and in diuers parts thereof, to erect and cast downe againe, to establish and to destroy, and to bring all things, Persons and States; to the same certaine ends, which the infinite spirit of the Vniuersall, piercing, mouing, and gouerning all thinges hath ordained. Certainely the things that this King did were maruailous, and would hardly haue beene vndertaken by any man else: and though his Father had determined to haue inuaded the lesser Asia it is like enough that he would haue contented himselfe with some part thereof, and not haue discouered 
the Riuer of Indus, as this man did. The swift course of victorie, wherewith he ranne ouer so large a portion of the World, in so short a space, may justly be imputed vnto this, That he was neuer encountred by an equall spirit, concurring with equall power against him. Hereby it came to passe that his actions being limited by no greater opposition, than Desert places, and the meere length of tedious journies could make, were like the Colossus of Rhodes, not so much to bee admired for the workemanship, though therein also praise-worthie, as for the huge bulke. For certainely the things performed by Xenophon, discouer as braue a spirit as Alexanders, and working no lesse exquisitely, though the effects were lesse materiall, as were also the forces and power of command, by which it wrought. But he that would finde the exact patterne of a noble Commander, must looke vpon such as Epaminondas, that encountring worthie Captains, and those better followed than themselues, haue by their singular vertue ouer-topped their valiant enemies, and still preuailed ouer those, that would not haue yeelded one foot to any other. Such as these are doe seldome liue to obtaine great Empires. For it is a worke of more labour and longer time, to master the equall forces of one hardie and wellordered State, than to tread downe and vtterly subdue a multitude of seruile Nations, compounding the bodie of a grosse vnweldie Empire. Wherefore these Paruo Potentes, men that with little haue done much vpon enemies of like abilitie, are to be regarded as choise examples of worth; but great Conquerors, to bee rather admired for the substance of their actions, than the exquisite menaging: exactnesse and greatnesse concurring so seldome, that I can finde no instance of both in one, saue only that braue Roman $C_{e}$ sar.

Hauing thus farre digressed, it is now time that wee returne vnto our Easterne Conqueror; who is trauailing hastily towards Cilicia, with a desire to recouer the Streights thereof before Darius should arriue there. But first making a dispatch into Greece, he sent to those Cities, in which he reposed most trust, some of the Persian Targets which he had recouered in his first battaile; vpon which, by certaine inscriptions, he made them partakers of his victorie. Herein hee well aduised himselfe; for he that doth not aswell impar1 
of the honour which he gaineth in the Warres, as hee doth of the spoiles, shall neuer bee long followed by those of the better sort. For men which are either well borne or well bred, and haue more of wealth than of reputation, doe as often satisfie themselues with the purchase of glorie; as the weake in fortune, and strong in courage, doe with the gaine of gold and siluer.

The Gouernour of Cilicia hearing of Alexander comming on, left some Companies to keepe the Streights, which were indeede very defencible; and withall, as Curtius noteth, hee beganne ouer-late to prise and put in execution the Counsell of Memnon: who in the beginning of the Warres aduised him to wast all the prouisions for Men and Horse, that could not bee lodged in strong places, and alwaies to giue ground to the Inuader, till hee found some such notable aduantage as might assuredly promise him the obtaining of victorie. For the furie of an inuading Armie is best broken, by delaies, change of diet, and want, eating sometimes too little, and sometimes too much, sometimes reposing themselues in beds, and more oftner on the cold ground. These and the like suddaine alterations bring many diseases vpon all Nations out of their owne Countries. Therefore if Darius had kept the Macedonians but a while from meat and sleepe, and refusing to giue or take battaile, had wearied them with his light horse, as the Parthians afterward did the Romans; hee might perchance haue saued his owne life, and his estate: For it was one of the greatest incouragements giuen by Alexander to the Macedonians, in the third and last fatall battaile, that they were to fight with all the strength of Persia at once.

Xerxes when he inuaded Greece and fought abroade, in being beaten, lost only his men; but Darius being inuaded by the Greekes, and fighting at home, by being beaten, lost his Kingdome; Pericles, though the Lacedemonians burnt all in Attica to the Gates of Athens, yet could not bee drawne to hazard a battaile: for the inuaded ought euermore to fight vpon the aduantage of time and place. Because we reade Histories to informe our vnderstanding by the examples therein found, we will giue some instances of those that haue perished by aduenturing in their owne Countries, to charge 
an inuading Armie. The Romans, by fighting with Hanibal, were brought to the brinke of their destruction.

Pompey was well aduised for a while, when hee gaue Cesar ground, but when by the importunitie of his Captaines he aduentured to fight at Pharsalia, he lost the battaile, lost the freedome of Rome, and his owne life.

Ferdinand, in the Conquest of Naples, would needs fight a battaile with the French to his confusion, though it was told him by a man of sound judgement, that those Counsels which promise suretie in all things, are honourable enough.

The Constable of France made frustrate the mightie preparation of Charles the First, when he inuaded Prouence, by wasting the Countrie, and forbearing to fight; so did the Duke of Alua wearie the French in Naples, and dissolue the boisterous Armie of the Prince of Orenge in the lowCountries.

The Leigers, contrarie to the aduise of their Generall, would needes fight a battaile with the Bourgonians, inuading their Countrie, and could not be perswaded to linger the time, and stay their aduantage; but they lost eight and twentie thousand vpon the place. Philip of Valois set upon King Edward at Cressie, and King Iohn (when the English were well neare tired out, and would in short time by an orderly pursuit haue beene wasted to nothing) constrained the black Prince with great furie, neare Poitiers, to joyne battaile with him: But all men know what lamentable successe these two French Kings found. Charles the Fift of France made an other kinde of Tabian Warfare; and though the English burnt and wasted many places, yet this King held his resolution to forbeare blowes, and followed his aduise which told him, That the English could neuer get his inheritance by smoake; and it is reported by Bellarus and Herrault, that King Edward was wont to say of this Charles, that hee wanne from him the Duchie of Guien without euer putting on his Armour.

But where God hath a purpose to destroy, wise men grow short liued, and the charge of things is committed vnto such as either cannot see what is for their good, or know not how to put in execution any sound aduise. The course which Memnon had propounded, must in all appearance of reason 
haue brought the Macedonian to a great perplexitie, and made him stand still a while at the Streights of Cilicia, doubting whether it were more shamefull to returne; or dangerous to proceede. For had Cappadocia and Paphlagonia beene wasted whilest Alexander was farre off; and the Streights of Cilicia beene defended by Arsenes, Gouernor of that Prouince, with the best of his forces: hunger would not haue suffered the enemie, to stay the triall of all meanes that might be thought vpon, of forcing that passage; or if the place could not haue beene maintained, yet might Cilicia at better leisure haue beene so throughly spoiled, that the heart of his Armie should haue beene broken; by seeking out miseries with painefull trauaile.

But Arsenes leauing a small number to defend the Streights, tooke the best of his Armie with him, to wast, and spoile the Countrie; or rather, as may seeme, to find himselfe some worke; by pretence of which hee might honestly runne further away from Alexander. Hee should rather haue aduentured his person in custodie of the Streights, whereby hee might perhaps haue saued the Prouince; and in the meane time, all that was in the fields, would haue beene conueighed into strong Townes. So should his Armie, if it were driuen from the place of aduantage, haue found good entertainement within walled Cities, and himselfe with his horse-men haue had the lesse worke in destroying that little which was left abroade. Handling the matter as he did, he gaue the Cilicians cause to wish for Alexanders comming, and as great cause to the Keepers of the passage not to hinder it. For cowards are wise in apprehending all formes of danger. These Guardians of the Streights, hearing that Arsenes made all hast to joyne himselfe with Darius, burning downe all as he went, like one despairing of the defence, beganne to grow circumspect, and to thinke that surely their Generall, who gaue as lost the Countrie behinde their backs, had exposed themselues vnto certaine death, as men that were good for nothing else, but to dull the Macedonian swords. Wherefore, not affecting to die for their Prince and Countrie (which honour they saw that Arsenes himselfe could well forbeare) they speedily followed the foote-steps of their Generall, gleaning after his 
Haruest. Thus Alexander without labour got both the entrance of Cilicia, abandoned by the cowardise of his Enemies, and the whole Prouince that had beene alienated from the Persian side by their indiscretion.

\$4. Of the vnwarlike Armie leauied by Darivs against Alexander. The vnaduised courses which Darivs tooke in this expedition. Hee is vanquished at Issus; where his Mother, Wife, and Children are made prisoners. Of some thinges following the battaile of Issus.

In the meane season Darius approched; who (as Curtius reports) had compounded an Armie of more than two hundred and ninetie thousand Souldiers, out of diuers Nations; Iustine musters them at three hundred thousand Foot, and a hundred thousand Horse; Plutarch at sixe hundred thousand.

The manner of his comming on, as Curtius describes it, was rather like a masker than a man of Warre, and like one that tooke more care to set out his glorie and riches, than to prouide for his owne safetie, perswading himselfe, as it seemed, to beat Alexander with pompe and sumptuous Pageants. For, before the Armie there was carried the holy fire which the Persians worshipped, attended by their Priests, and after them three hundred and threescore and fiue yong-men, answering the number of the daies of the yeare, couered with Scarlet; then the Chariot of Iupiter drawne with white Horses, with their Riders cloathed in the same colour, with rods of gold in their hands; And after it, the Horse of the Sunne: Next after these followed ten sumptuous Chariots, inlaied and garnisht with siluer and gold, and then the Vantguard of their horse, compounded of twelue seuerall Nations, which the better to auoide confusion, did hardly vnderstand each others language, and these marshalled in the head of the rest, being beaten, might serue very fitly to disorder all that followed them; in the taile of these Horses the Regiment of foote marched, with the Persians called immortall, because if any died the number was presently supplied: and these were armed with chaines 
of gold, and their coates with the same mettall imbrodered, whereof the sleeues were garnished with pearle, baites, either to catch the hungrie Macedonians withall, or to perswade them that it were great inciuilitie to cut and to deface such glorious garments. But it was well said. . . . Let no man thinke that he exceedeth those in valour, whom hee exceedeth in gay garments, for it is by men armed with fortitude of minde, and not by the apparell they put on, that enemies are beaten. And it was perchance from the Roman Papyrius that this aduice was borrowed, who when he fought against the Samnites in that fatall battaile, wherein they all sware either to preuaile or die, thirtie thousand of them hauing apparelled themselues in white garments, with high crests and great plumes of feathers, bad the Roman Souldiers to lay aside all feare: Non enim cristas vulnera facere, EO per picta atque aurata scuta transire Romanum pilum; For these plumed crests would wound no bodie, and the Roman pile would bore holes in painted and gilded shields.

To second this Court-like companie, fifteene thousand were appointed more rich and glittering than the former, but apparelled like Women (belike to breede the more terrour) and these were honoured with the Title of the Kings Kinsmen. Then came Darius himselfe, the Gentleman of his Guarde-robe, riding before his Chariot, which was supported with the Gods of his Nation, cast and cut in pure gold; these the Macedonians did not serue, but they serued their turnes of these, by changing their massie-bodies into thinne portable and currant coine. The head of this Chariot was set with pretious stones, with two little golden Idols, couered with an open-winged-Eagle of the same metall: The hinder part being raised high wheron Darius sate, had a couering of inestimable value. This Chariot of the King was followed with ten thousand Horse-men, their Lances plated with sluer, and their heads guilt; which they meant not to imbrew in the Macedonian bloud, for feare of marring their beautie. He had for the proper Guard of his person two hundred of the bloud Royall, bloud too Royall and pretious to be spilt by any valorous aduenture, (I am of opinion that two hundred sturdie fellowes, like the Switzers, would haue done him more seruice) and these were backt with thirtie 
thousand foot-men, after whome againe were led foure hundred spare horses for the King, which if hee had meant to haue vsed he would haue marshalled somewhat nearer him.

Now followed the Reareward, the same being led by Sisygambis the Kings Mother, and by his Wife, drawne in glorious Chariots, followed by a great traine of Ladies their attendants on horse-back, with fifteene Wagons of the Kings children, and the wiues of the Nobilitie, waited on by two hundred and fiftie Concubines, and a world of Nurses, and Eunuchs, most sumptuously apparelled, By which it should seeme that Darius thought that the Macedonians had beene Comedians or Tumblers; for this troupe was farre fitter to behold those sports than to bee present at battailes. Betweene these $\&$ a companie of slight-armed slaues, with a world of Vallets, was the Kings treasure, charged on sixe hundred Mules, and three hundred Camels, brought, as it proued, to pay the Macedonians. In this sort came this Maygame-King into the field, incombred with a most vnnecessarie traine of Strumpets, attended with troupes of diuers Nations, speaking diuers languages, and for their numbers impossible to be marshalled, and for the most part so effeminate, and so rich in gold and in garments, as the same could not but haue incouraged the nakeddest Nation of the world against them. We finde it in daily experience that all discourse of magnanimitie, of Nationall Vertue, of Religion, of Libertie, and whatsoeuer else hath beene wont to moue and incourage vertuous men, hath no force at all with the common-Souldier in comparison of spoile and riches, The rich ships are boorded vpon all disaduantages, the rich Townes are furiously assaulted, and the plentifull Countries willingly inuaded. Our English Nation haue attempted many places in the Indies, and runne vpon the Spaniards head-long, in hope of their Royalls of plate, and Pistolets, which had they beene put to it vpon the like disaduantages in Ireland, or in any poore Countrie, they would haue turned their Peeces and Pikes against their Commanders, contesting that they had beene brought without reason to the Butcherie and slaughter. It is true that the warre is made willingly, and for the most part with good 
successe, that is ordained against the richest Nations; for as the needie are alwaies aduenturous, so plentie is wont to shunne perill, and men that haue well to liue, doe rather studie how to liue well, I meane wealthily, than care to die (as they call it) honourably. Car où il ny' a rien a gaigner, que des coups volontiers il ny' va pas; No man makes hast to the market, where there is nothing to be bought but blowes.

Now if Alexander had beheld this preparation before his consultation with his Southsaiers, hee would haue satisfied himselfe by the out-sides of the Persians, and neuer haue looked into the intrailes of Beasts for successe. For leauing the description of this second battaile (which is indeede nowhere well described, neither for the confusion and hastie running away of the Asians could it be) we haue enough by the slaughter that was made of them, and by the few that fell of the Macedonians, to informe vs what manner of resistance was made. For if it be true that threescore thousand Persian foot-men were slaine in this Battaile, with ten thousand of their horsemen, Or (as Curtius saith) an hundred thousand footmen, with the same number of horsemen, and besides this slaughter, fortie thousand taken prisoners, while of Alexanders Armie there miscarried but two hundred and fourescore of all sorts, of which numbers Arianus and other Historians cut off almost the one halfe: I doe verily beleeue that this small number rather died with the ouer-trauaile and paines-taking in killing their enemies, than by any strokes receiued from them. And surely if the Persian Nation (at this time degenerate and the basest of the World) had had any sauour remaining of the ancient valour of their forefathers; they would neuer haue sold so good cheape, and at so vile a price, the Mother, the Wife, the Daughters, and other the Kings children; had their owne honor beene valued by them at nothing, and the Kings safetie and his estate at lesse. Darius by this time found it true that Charidemus a banished Grecian of Athens had told him, when hee made a view of his Armie about Babylon, to wit, That the multitude which hee had assembled of diuers Nations, richly attired, but poorely armed, would bee found more terrible to the Inhabitants of the countrie, whom in passing by they would deuour, than to the Macedonians, 
whom they meant to assaile; who being all old and obedient Souldiers, imbattailed in grosse squadrons, which they call their Phallanx, well couered with Armour for defence, and furnished with weapons for offence of great aduantage, would make so little accompt of his delicate Persians, louing their ease and their palat, being withall ill armed and worse disciplined, as except it would please him to entertaine (hauing so great aboundance of treasure to doe it withall) a sufficient number of the same Gracians, and so to encounter the Macedonians with men of equall courage, hee would repent him ouer-late, as taught by the miserable successe like to follow.

But this discourse was so vnpleasing to Darius (who had beene accustomed to nothing so much as to his owne praises, and to nothing so little as to heare truth;) as he commanded that this poore Grecian should bee presently slaine: who while hee was a sundring in the Tormentors hand, vsed this speech to the King, That Alexander, against whom hee had given this good counsell, should assuredly reuenge his death, and lay deserued punishment vpon Darius for despising his aduise.

It was the saying of a Wise man. Desperata eius Principis salus est, cuius aures ita formate sunt, vt aspera que vtilia, nec quicquam nisi iucundum accipiat; That Princes safetie is in a desperate case, whose eares iudge all that is profitable to bee too sharpe, and will entertaine nothing that is onpleasant.

For libertie in counsell is the life and essence of counsell; Libertas consilij est eius vita, Eे essentia, qua erepta consilium euanescit.

Darius did likewise value at nothing the Aduise giuen him by the Grecian Souldiers that serued him, who intreated him not to fight in the Streights: but had they beene Counsellers and directors in that Warre, as they were vnderlings and commanded by others, they had with the helpe of a good troupe of horse-men beene able to haue opposed the furie of Alexander, without any assistance of the Persian foot-men. For when Darius was ouerthrowne with all his cowardly and confused rabble, those Gracians, vnder their Captaine Amyntas, held firme, and marched away in order in despight of the vanquishers. Old Souldiers are not 
easily dismaied: we reade in Histories ancient and moderne, what braue retraits haue beene made by them, though the rest of the Armie in which they haue serued, hath beene broken.

At the battaile of Rauenne where the Imperialls were beaten by the French, a squadron of Spaniards, old Souldiers, came off vnbroken and vndismaied; whom when Gaston de Foix, Duke of Nemures, and Nephew to Lewis the twelfth, charged, as holding the victorie not intire by their escape, hee was ouer-turned and slaine in the place. For it is truely said of those men, who, by being acquainted with dangers feare them not, That, Neglecto periculo imminentis mali opus ipsum quantumuis difficile aggrediuntur; They goe about the businesse it selfe, how hard soeuer it be, not standing to consider of the danger, which the mischiefe hanging ouer their heads may bring: and as truely of those that know the warres but by heare-say. Quod valentes sunt E preualentes ante pericula, in ipsis tamen periculis discedunt; They haue abilitie enough, and to spare, till dangers appeare; but when perill indeede comes they get them gone.

These Grecians also that made the retract, aduised Darius to retire his Armie into the plaine of Mesopotamia, to the end that Alexander being entred into those large fields and great Champions, he might haue inuironed the Macedonians on all sides with his multitude; and withall they counselled him to diuide that his huge Armie into parts, not committing the whole to one stroke of Fortune, whereby he might haue fought many battailes, and haue brought no greater numbers at once then might haue beene well marshalled and conducted. But this counsell was so contrarie to the cowardly affections of the Persians, as they perswaded Darius to inuirone the Gracians which gaue the aduise, and to cut them in peeces as Traitors. The infinite wisedome of God doth not worke alwaies by one and the same way, but very often in the alteration of Kingdomes and Estates, by taking vnderstanding from the Gouernours, so as they can neither giue nor discerne of Counsels. For Darius that would needes fight with Alexander vpon a straightned peece of ground, neare vnto the Citie of Issus, where he could bring no more hands to fight than Alexander could, (who by the aduise of 
Parmenio staied there, as in a place of best aduantage) was vtterly ouerthrowne, his Treasure lost, his Wife, Mother, and Children (whom the Grecians his followers had perswaded him to leaue in Babylon, or elsewhere) taken prisoners, and all their traine of Ladies spoiled of their rich Garments, Iewels, and Honour. It is true, that both the Queene, with her Daughters, who had the good hap to be brought to Alexanders presence, were entertained with all respect due vnto their birth, their Honours preserued, and their Iewels and rich Garments restored vnto them; and though Darius Wife was a most beautifull Ladie, and his Daughters of excellent forme, Yet Alexander mastred his affections towards them all: only it is reported out of Aristobulus the Historian, That he imbraced the Wife of the valiant Memnon, her Husband lately dead, who was taken flying from Damascus by Parmenio, at which time the Daughters of Ochus, who raigned before Darius, and the Wiues and Children of all the Nobilitie of Persia in effect, fell into captiuitie; At which time also Darius Treasure (not lost at Issus) was seized, amounting to sixe thousand and two hundred talents of coine, and of Bullion fiue hundred talents, with a world of riches besides.

Darius himselfe leauing his brother dead, with diuers other of his chiefe Captaines (casting the Crowne from his head) hardly escaped.

After this ouerthrow giuen vnto Darius, all Phonicia (the Citie of Tyre excepted) was yeelded to Alexander, of which Parmenio was made Gouernour.

Aradus, Zidon, and Biblos, Maritimate Cities of great importance, of which one Strato was King (but hated of the people) acknowledged Alexander. Good fortune followed him so fast that it troade on his heeles, for Antigonus, Alexanders Lieutenant in Asia the lesse, ouerthrew the Cappadocians, Paphlagonians, and others lately reuolted; Aristodemus, Darius Admirall, had his Fleet partly taken, and in part drowned by the Macedonians newly leauied; the Lacedemonians that warred against Antipater were beaten; foure thousand of those Greekes which made the retrait at the last battaile, forsaking both the partie of Darius and of Alexander, and led by Amyntas into $\mathscr{E g y p t}$, to hold it for themselues, 
were buried there; for the time was not yet come to diuide Kingdomes.

Alexander, to honour Ephestion, whom hee loued most, gaue him power to dispose of the Kingdome of Zidon. A man of a most poore estate; that laboured to sustaine his life; being of the Royall bloud, was commended by the people vnto him, who changed his Spade into a Scepter, so as he was beheld both a Beggar and a King in one and the same houre.

It was a good desire of this new King, when speaking to Alexander, he wisht that hee could beare his prosperitie with the same moderation, and quietnesse of heart, that he had done his aduersitie; but ill done of Alexander, in that he would not performe in himselfe that which hee commended in an other mans desire: for it was a signe that he did but accompanie, and could not gouerne, his felicitie.

While he made some stay in those parts, he receiued a letter from Darius, importing the ransome of his Wife, his Mother, and his Children, with some other conditions of peace, but such as rather became a Conqueror, than one that had now been twice shamefully beaten, not vouchsafing, in his direction, to stile Alexander King. It is true, that the Romans, after that they had receiued an ouerthrow by Pyrrhus, returned him a more scornefull answere vpon the offer of peace, than they did before the triall of his force. But as their fortunes were then in the Spring, so that of Darius had alreadie cast leafe, the one a resolued well armed and disciplined Nation, the other cowardly and effeminate. Alexander disdained the offers of Darius, and sent him word that he not only directed his letter to a King, but to the King of Darius himselfe.

\section{\$5. How Alexander besieged and wanne the Citie of Tyre.}

Alexander comming neare to the Citie of Tyre, receiued from them the present of a golden Crowne, with great store of victualls, and other presents, which hee tooke very thankefully, returning them answere, That he desired to offer a sacrifice to Hercules, the Protector of their Citie, from whom 
hee was descended. But the Tyrians like not his companie within their Walles, but tell him that the Temple of Hercules was seated in the old Citie adjoyning, now abandoned and desolate: To bee short, Alexander resolued to enter it by force, and though it were a place in all mens opinion impregnable, because the Iland whereon it was built, was eight hundred furlongs from the Maine; yet with the labour of many hands, hauing great store of stone from the old Tyre, and timber sufficient from Lybanus, hee filled the passage of the Sea betweene the Iland and the Maine, which being more than once carried away by the strength of the Sea vpon a storme of winde, sometime by the Tyrians fired, and sometime torne a-sunder, yet with the helpe of his Nauie which arriued (during the siege) from Cyprus, he ouercame all difficulties and preuailed, after he had spent seuen Moneths in that attempt. The Tyrians in the beginning of the siege had barbarously drowned the messengers sent by Alexander, perswading them to render the Citie, in respect whereof, and of the great losse of time and men, he put eight thousand to the sword, and caused two thousand of those, that escaped the first furie, to bee hanged on Crosses on the Sea-shore, and reserued for slaues (saith Diodore) thirteene thousand; Arrianus reckons them at thirtie thousand. Many more had died had not the Zidonians, that serued Alexander, conueied great numbers away by shipping vnto their owne Citie.

Happie it was for Apollo that the Towne was taken, for one of the Tyrians hauing dreamt, that this God meant to forsake the Citie, they bound him fast with a golden chaine to the Idoll of Hercules; but Alexander like a gratious Prince loosened him againe.

It is true, that it was a notable enterprise and a difficult, but great things are made greater. For Nabuchodonosor had taken it before, and filled vp the channell, that lay betweene the Iland and the Maine.

The gouernement of this Territorie he gaue to Philotas, the Sonne of Parmenio; Cilicia, he committed to Socrates, and Andromachus Lieutenant vnder Parmenio; Ephestion had the charge of the Fleet, and was directed to finde Alexander at Gaza towards Agypt. 
\$6. How Darivs offered conditions of peace to Alexander. Alexander winnes Gaza; and deales graciously with the Ierves.

In the meane while Darius sends againe to Alexander, sets before him all the difficulties of passing on towards the East; and laieth the losse of the last battaile to the straightnesse of the place: he hoped to terrifie him, by threatning to incompasse him in the plaine Countries, he bids him consider, how impossible it was to passe the Riuers of Euphrates, Tigris, Araxes, and the rest, with all such other fearefull thinges: for, hee that was now filled with nothing but feare, had arguments enough of that nature to present vnto another. All the Kingdomes betweene the Riuer of Alys, and the Hellespont, he offered him in Dower with his beloued daughter. But Alexander answered, That he offered him nothing but his owne, and that which victorie and his owne vertue had possest him of; That he was to giue conditions, and not to receiue any; and that he hauing passed the Sea it selfe, disdained to thinke of resistance in transporting himselfe ouer Riuers. It is said that Parmenio, who was now old and full of honour and riches, told the King, that were he Alexander hee would accept of Darius his offers, to which Alexander answered, That so would he if he were Parmenio.

But he goes on towards Egypt, and comming before Gaza, Betis a faithfull seruant to Darius, shuts the Gate against him, and defends the Towne with an obstinate resolution, at the siege whereof Alexander receiued a wound in the shoulder, which was dangerous, and a blow on his legge with a stone; Hee found better men in this place than he did at the former battailes, for he left so many of his Macedonians buried in the sands of Gaza, that he was forst to send for a new supply into Greece. Here it was that Alexander first beganne to change condition, and to exercise crueltie. For after that he had entred Gaza by assault, and taken Betis, (whom Iosephus calleth Babemeses) that was weakened with many wounds, and who neuer gaue ground to the Assailants; he bored holes through his feete, and caused him to bee drawne about the streets, whilest he was as yet aliue; who being as valiant a man as himselfe, 
disdained to aske him either life or remission of his torments. And what had hee to countenance this his tyrannie, but the imitation of his ancestor Achilles, who did the like to Hector? It is true, that crueltie hath alwaies somewhat to couer her deformitie.

From Gaza (saith Iosephus) he led his Armie towards Ierusalem, a Citie, for the antiquitie and great fame thereof, well knowne vnto him while he lay before Tyre; He had sent for some supply thither, which Iaddus the high Priest, being subject and sworne to Darius, had refused him. The Iewes therefore fearing his reuenge, and vnable to resist, committed the care of their estates and safetie to Iaddus, who, being taught by God, issued out of the Citie couered with his Pontificall-Robes, to wit, an vpper garment of purple, embrodered with gold, with his Miter, and the plate of gold wherein the name of God was written, the Priests \& Leuites in their rich ornaments, and the people in white garments, in a maner so vnusuall, stately, and graue, as Alexander greatly admired it. Iosephus reports it, that he fell to the ground before the high Priest, as reuerencing the name of God, and that Parmenio reprehended him for it; Howsoeuer it was, I am of opinion, That he became so confident in his enterprise, and so assured of the successe after the prophecie of Daniel had been read vnto him, wherein he saw himselfe, and the conquest of Persia so directly pointed at, as nothing thence-forth could discourage him or feare him. He confessed to Parmenio (saith Iosephus) That in Dio a Citie of Macedon, when his mind laboured the conquest of $A$ sia, hee saw in his sleepe such a person as Iaddus, and so apparailed, professing one and the same God, by whom he was incouraged to pursue the purpose hee had in hand with assurance of victorie. This apparition, formerly apprehended only by the light of his phantasie, he now beheld with his bodily eies; wherewith he was so exceedingly pleased and imboldened, as contrarie to the practice of the Phonicians, (who hoped to haue sackt and destroied Ierusalem) he gaue the Iewes all, and more than they desired, both of libertie and immunitie, with permission to liue vnder their owne lawes, and to exercise and enjoy their owne Religion. 
\$7. Alexander winnes Egypt: and makes a iournie to the Temple of Hammon.

From Ierusalem Alexander turned againe towards $E_{\text {ggypt }}$, and entred it, where Darius his Lieutenant, Astaces, receiued him and deliuered into his hand the Citie of Memphis, with eight hundred talents of treasure, and all other the Kings riches. By this wee see that the Kings of Persia, who had more of affection than of judgement, gaue to the valiantest man hee had but the command of one Citie, and to the veriest coward the gouernement of all Egypt. When he had set thinges in order in $E_{g y p t}$, he beganne to trauaile after God-head, towards Iupiter Hammon, so foolish had prosperitie made him, $\mathrm{He}$ was to passe ouer the dangerous and drie sands, where, when the water which he brought on his Camels-back was spent, hee could not but haue perished, had not a maruailous shower of raine fallen vpon him, when his Armie was in extreme despaire. All men that know Egypt, and haue written thereof, affirme, That it neuer raines there; but the purposes of the Almightie God are secret, and he bringeth to passe what it pleaseth him; for it is also said, That when he had lost his way in those vast desarts, that a flight of Crowes flew before the Armie; who making faster wing when they were followed, and fluttering slowly when the Armie was cast back, guided them ouer those pathlesse sands to Iupiters Temple.

Arrianus from the report of Ptolomie, the sonne of Lagus, saies, That hee was led by two Dragons, both which reports may be a-like true; But many of these wonders and thinges prodigious, are fained by those that haue written the Storie of Alexander, as that an Eagle lay houering directly ouer his head at the battaile of Issus; That a Swallow flew about his head when hee slept, and could not be feared from him, till it had wakened him, at Halicarnasseus, fore-shewing the treason of Eropus, practised by Darius to haue slaine him; That from the yron barres of which the Tyrians made their defensiue ingines, when Alexander besieged them, there fell drops of bloud; and that the like drops were found in a loafe of bread, broken by a Macedonian Souldier, at the same time; That a Turfe of earth fell on his shoulder, when he 
lay before Gaza, out of which there flew a Bird into the aire. The Spaniards in the conquest of the West Indies haue many such pretie tales; telling how they haue been assisted in battaile, by the presence of our Ladie, and by Angels riding on white horses, with the like Romish miracles, which I thinke themselues doe hardly beleeue. The strangest things that I haue read of in this kind being certainely true was, That the night before the battaile at Nouarre, all the Dogges which followed the French Armie, ranne from them to the Switzers, leaping and fawning vpon them, as if they had beene bred and fed by them all their liues, and in the morning following, Triuulzi and Tremouille, Generals for Lewis the twelfth, were by these Imperiall Switzers vtterly broken and put to ruine.

The place of this Idoll of Iupiter Hammon is ill described by Curtius, for he bounds it by the Arabian Troglodites on the south, between whom and the territorie of Hammon, the Region Thebais, or the superiour $E g y p t$, with the Mountaines of Lybia, and the Riuer of Nilus, are interjacent, and on the North he joynes it to a Nation, called Nassamones, who bordering the Sea-shore, liue (saith hee) vpon the spoiles of shipwrack, whereas the Temple or Groue of this Idoll hath no Sea neare it by two hundred miles and more, being found on the South part of Lybia; these Nassamones being due West from it, in the South part of Marmarica.

When Alexander came neare the place, he sent some of his Parasites before him to practise the Priests attending the Oracle, That their answere might bee giuen in all thinges, agreeable to his madde ambition, who affected the title of Iupiters sonne. And so hee was saluted Sonne of Iupiter by the Deuils Prophet, whether prepared before to flatter him, or rather (as some thinke) defectiue in the Greeke tongue; For whereas he meant to say Opaidion, he said Opaidios, that is; $O$ sonne of Iupiter, in stead of, $O$ deare sonne: for which Grãmaticall error he was richly rewarded, and a rumor presently spread, that the great Iupiter had acknowledged Alexander for his owne.

He had heard that Perseus and Hercules had formerly consulted with this Oracle, The one, when he was imploied against Gorgon, The other, against Anteus and Busiris; and 
seeing these men had deriued themselues from the Gods, why might not hee? By this it seemes, that he hoped to make his followers and the world fooles, though indeede he made himselfe one, by thinking to couer from the Worlds knowledge his vanities and vices; and the better to confirme his followers in the beliefe of his Deitie, hee had practized the Priests to giue answere to such as consulted with the Oracle, that it should be pleasing to Iupiter to honour Alexander as his Sonne.

Who this Ammon was, and how represented, either by a bosse carried in a Boate, or by a Ramme, or a Rammes-head; I see that many wise-men haue troubled themselues to finde out; but, as Arrianus speakes of Dionysius, or Liber Pater (who liued saith St. Augustine in Moses time), Ea qua de dijs veteres fabulis suis conscripsere non sunt nimium curiosè peruestiganda; We must not ouer-curiously search into the fables, which the Ancients haue written of their Gods.

But this is certaine and notable, that after the Gospell beganne to be preached in the World, the Deuill in this and in all other Idols became speechlesse. For that this Hammon was neglected in the time of Tiberius Cesar, and in the time of Traian altogether forgotten, Strabo and Plutarch witnesse.

There is found neare his Temple a Fountaine called Fons solis (though Ptolomie in his third African Table sets it farther off) that at mid-night is as hot as boiling water, and at Noone as cold as any yce, to which I cannot but giue credit, because I haue heard of some other Wells of like nature, and because it is reported by Saint Augustine, by Diodore, Herodotus, Plinie, Mela, Solinus, Arianus, Curtius, and others, and indeede our Bathes in England are much warmer in the night, than in the day.

\$8. How Alexander marching against Darivs, was opposed very vnskilfully by the Enemie.

From the Temple of Hammon he returned to Memphis, where among many other learned men he heard the Philosopher Psammones, who, belike vnderstanding that he affected the title of Iupiters Sonne, told him that God was the 
Father-King of all men in generall; and refining the pride of this haughtie King, brought him to say, That God was the Father of all mortall men, but that hee acknowledged none for his children saue good men.

He gaue the charge of the seuerall Prouinces of $\mathbb{E g y p t}$ to seuerall Gouernours, following the rule of his Master Aristotle, That a great Dominion should not bee continued in the hands of any one: whom therein the Roman Emperours also followed, not daring to commit the gouernement of $\not E g y p t$ to any of their Senators, but to men of meaner ranck and degree. He then gaue order for the founding of Alexandria vpon the Wester-most branch of Nilus. And hauing now setled (as he could) the estate of $A g y p t$, with the Kingdomes of the lesser Asia, Phonicia, and Syria, (which being but the pawnes of Darius his ill fortune, one happie victorie would readily haue redeemed;) he led his Armie towards Euphrates, which passage though the same was committed to Mazeus to defend, yet was it abandoned, and Alexander without resistance past it. From thence he marched towards Tigris, a Riuer for the swiftnesse thereof called by the Persians The Arrow. Here, as Curtius, and Reason it selfe tells vs, might Darius easily haue repelled the inuading Macedonian: for the violent course of the streame was such, as it draue before it many waightie stones, and those that moued not but lay in the bottome, were so round and well polished by continuall rolling, that no man was able to fight on so slipperie a footing; nor the Macedonian foot-men to wade the Riuer, otherwise than by joyning their handes and enterlacing their Armes together, making one waightie and entire bodie to resist the swift passage and furious race of the streame. Besides this notable helpe; the Channell was so deepe towards the Easterne shore, where Darius should haue made head, as the foot-men were inforst to lift their Bowes and Arrowes and Darts ouer their heads, to keepe them from being moistned, and made vnseruiceable by the Waters. But it was truely and vnderstandingly said of Homer.

Talis est hominum terrestrium mens,

Qualis quotidie ducit pater virorumque Deorumque.

The mindes of men are euer so affected, As by Gods will they daily are directed. 
And it cannot be denied, that as all Estates of the World by the surfeit of misgouernement haue beene subject to many grieuous, and sometimes mortall diseases, So had the Empire of Persia at this time brought it selfe into a burning and consuming Feuer, and thereby become frantick and without vnderstanding, foreshewing manifestly the dissolution and death thereof.

But Alexander hath now recouered the Easterne shores of Tigris, without any other difficultie, than that of the nature of the place; where Mazeus (who had charge to defend the passage both of Euphrates and it) presented himselfe to the Macedonians, followed with certaine companies of Horsemen, as if with vneuen forces hee durst haue charged them on euen ground, when as with a multitude farre exceeding them hee forsooke the aduantage which no valour of his enemies could easily haue ouer-come. But it is commonly seene, that fearefull and cowardly men doe euer follow those waies, and counsells, whereof the opportunitie is alreadie lost.

It is true that he set all prouisions a fire wherewith the Macedonians might serue themselues ouer Tigris, thinking thereby greatly to haue distressed them; but the execution of good counsell is fruitlesse when vnseasonable. For now was Alexander so well furnished with carriages, as nothing was wanting to the competencie of the Armie which he conducted. Those thinges also which he sought to wast, Alexander being now in sight, were by his Horse-men saued and recouered. This, Mazeus might haue done some daies before at good leisure; or at this time with so great a strength of horse-men, as the Macedonians durst not haue pursued them, leauing the strength of their foote out of sight, and farre behinde.

\$9. The new prouisions of Darivs. Accidents foregoing the battaile of Arbela.

Darivs, vpon Alexanders first returne out of Egypt, had assembled all the forces, which those Regions next him could furnish, and now also were the Arians, Scythians, Indians, SWR K 
and other Nations arriued; Nations (saith Curtius) that rather serued to make vp the names of men, than to make resistance. Arianus hath numbred them with their Leaders; and finds of foot-men of all sorts ten hundred thousand, and of horse foure hundred thousand, besides armed Chariots, and some few Elephants. Curtius who musters the Armie of Darius at two hundred thousand foote, and neare fiftie thousand horse, comes (I thinke) nearer to the true number; and yet seeing he had more confidence in the multitude than in the valour of his Vassalls, it is like enough that hee had gathered together of all sorts some three or foure hundred thousand, with which hee hoped in those faire plaines of Assyria to haue ouer-borne the few numbers of the inuading Armie. But it is a Rule in the Philosophie of the Warre, In omni prelio non tam multitudo, E virtus indocta, quam ars $\mathcal{E}^{2}$ exercitium solent prestare victoriam; In euerie battaile skill and practise doe more towards the victorie, than multitude and rude audacitie.

While Alexander gaue rest to his Armie after their passage ouer Tigris, there happened an Eclipse of the Moone, of which the Macedonians, not knowing the cause and reason, were greatly affrighted. All that were ignorant, (as the multitude alwaies are) tooke it for a certaine presage of their ouerthrow and destruction, in so much as they began not only to murmur, but to speake it boldly, That for the ambition of one man, a man that disdained Philip for his Father, and would needes bee called the Sonne of Iupiter, they should all perish; For hee not only inforst them to make warre against Worlds of enemies, but against Riuers, Mountaines, and the Heauens themselues.

Hereupon Alexander being readie to march forward made a halt, and to quiet the mindes of the multitude, he called before him the Agyptian Astrologers, which followed him thence, that by them the Souldiers might bee assured that this defection of the Moone was a certaine presage of good successe; for that it was naturall they neuer imparted to the common people, but reserued the knowledge to themselues, so as a sorrie Almanack-maker had beene no small foole in those daies.

Of this kinde of superstitious obseruation Cesar made 
good vse, when he fought against Ariouistus and the Germans: for they being perswaded by the casting of lots, that if they fought before the change of the Moone, they should certainely loose the battaile, Cesar forst them to abide it, though they durst not giue it, wherein hauing their mindes alreadie beaten by their owne superstition, and being resolutely charged by the Romans, the whole Armie in effect perished.

These Agyptians gaue no other reason than this, That the Grecians were vnder the aspect of the Sunne, the Persians of the Moone; and therefore the Moone failing and being darkened, the state of Persia was now in danger of falling, and their glorie of being obscured. This judgement of the Egyptian Priests being noised through all the Armie, all were satisfied, and their courage redoubled. It is a principle in the Warre, which, though deuised since, was well obserued then. Exercitum terrore plenum Dux ad pugnam non ducat; Let not a Captaine leade his Armie to the fight, when it is possessed with matter of terrour.

It is truely obserued by Curtius, that the people are led by nothing so much as by superstition; yea, we finde it in all Stories, and often in our owne, that by such inuentions, deuised tales, dreames, and prophesies, the people of this Land haue beene carried head-long into many dangerous tumults and insurrections, and still to their owne losse and ruine.

As Alexander drew neare the Persian Armie, certaine letters were surprized written by Darius to the Grecians, perswading them for great summes of money, either to kill or betray Alexander. But these by the aduice of Parmenio he suppressed.

At this time also Darius his faire Wife, opprest with sorrow, and wearied with trauell, died. Which accident Alexander seemed no lesse to bewaile than Darius, who vpon the first brute suspected that some dishonourable violence had beene offered her, but being satisfied by an Eunuch of his owne that attended her, of Alexanders Kingly respect towards her, from the day of her being taken, he desired the immortall Gods, That if they had decreed to make a new Master of the Persian Empire, then it would please them to 
conferre it on so just and continent an enemie as Alexander, to whom he once againe before the last triall by battaile offered these conditions of peace.

That with his Daughter in marriage he would deliuer vp and resigne all Asia the lesse, and with Egypt, all those Kingdomes betweene the Phonician Sea, and the Riuer of Euphrates; That he would pay him for the ransome of his Mother, and his other Daughter thirtie thousand talents, and that for the performance thereof, hee would leaue his Sonne Occhus in hostage: To this they sought to perswade Alexander by such arguments as they had. Alexander causing the Embassadours to be remoued, aduised with his Counsell, but heard no man speake but Parmenio, the very right hand of his good fortune; who perswaded him to accept of these faire conditions. Hee told him, that the Empire betweene Euphrates and Hellespont was a faire addition to Macedon; that the retayning of the Persian prisoners was a great cumber, and the treasure offered for them of farre better vse than their persons, with diuers other arguments; all which Alexander rejected. And yet it is probable that if he had followed his aduise, and bonded his ambition within those limits, he might haue liued as famous for vertue as for fortune, and left himselfe a Successor of able age to haue enjoyed his estate, which afterward, indeed, he much inlarged, rather to the greatning of others than himselfe: who to assure themselues of what they had vsurped vpon his issues, left not one of them to draw breath in the world within a few yeares after. The truth is, That Alexander in going so farre into the East, left behinde him the reputation which he brought out of Macedon; the reputation of a just and prudent Prince, a Prince temperate, aduised and gratefull: and being taught new lessons by aboundance of prosperitie, became a louer of wine, of his owne flatterie, and of extreame crueltie. Yea, as Seneca hath obserued, the taint of one vnjust slaughter, amongst many, defaced and withered the flourishing beautie of all his great acts and glorious victories obtained. But the Persian Embassadors stay his answere, which was to this effect, That whatsoeuer he had bestowed on the Wife and Children of Darius, proceeded from his owne naturall clemencie and magnani- 
mitie, without all respect to their Master; that thankes to an enemie was improper; that he made no warres against aduersitie, but against those that resisted him, Not against Women and Children, but against armed enemies: and although by the reiterated practice of Darius, to corrupt his Souldiers, and by great summes of money to perswade his friends to attempt vpon his person, he had reason to doubt that the peace offered was rather pretended than meant, yet hee could not (were it otherwise and faithfull) resolue in hast to accept the same, seeing Darius had made the Warre against him, not as a King with Royall and ouert-force, but as a Traitor by secret and base practice; That for the Territorie offered him, it was alreadie his owne, and if Darius could beate him back againe ouer Euphrates, which hee had alreadie past, hee would then beleeue that he offered him somewhat in his owne power: Otherwise he propounded to himselfe for the reward of the Warre, which hee had made, all those Kingdomes as yet in Darius possession, wherein, whether he were abused by his owne hopes or no, the battaile which hee meant to fight in the day following should determine. For conclusion, hee told them, that hee came into Asia to giue, and not to receiue; That the Heauens could not hold two Sunnes: and therefore if Darius could bee content to acknowledge Alexander for his Superiour, hee might perchance bee perswaded to giue him conditions fit for a second Person, and his Inferiour.

\$10. The battaile of Arbela: and that it could not bee so strongly fought as report hath made it.

With this answer the Embassadors returne; Darius prepares to fight, and sends Mazeus to defend a passage, which he neuer yet dared so much as to hazard. Alexander consults with his Captaines, Parmenio perswades him to force Darius his Camp by night; so that the multitude of enemies might not moue terrour in the Macedonians, being but few. Alexander disdaines to steale the victorie, and resolues to bring with him the day-light, to witnesse his valour. But it was the successe that made good Alexanders resolution, though the 
counsell giuen by Parmenio was more sound: For it is a ground in Warre, Si pauci necessario cum multitudine pugnare cogantur, consilium est noctis tempus belli fortunam tentare. Notwithstanding vpon the view of the multitude at hand, he staggers $\&$ intrenches himselfe vpon a ground of aduantage, which the Persian had abandoned: And whereas Darius for feare of surprise had stood with his Armie in armour all the day, and forborne sleepe all the night; Alexander gaue his men rest and store of foode, for reason had taught him this Rule in the Warre, In pugna Milites validius resistunt, si cibo potuque refecti fuerint, nam fames intrinsecus magis pugnat, quam ferrum exterius; Souldiers doe the better stand to it in fight; if they haue their bellies full of meate and drinke; for hunger within, fights more eagrely than steele without.

The numbers which Alexander had, saith Arianus, were fortie thousand foote, and seuen thousand horse; these belike were of the Europacan Armie; for hee had besides both Syrians, Indians, Egyptians, and Arabians, that followed him out of those Regions. He vsed but a short speech to his Souldiers to incourage them; and I thinke that he needed little Rhetorick; for by the two former battailes vpon the Riuer of Granick and in Cilicia, the Macedonians were best taught with what men they were to encounter. And it is a true saying, Victoria Victoriam parat, animumque victoribus auget, $\mathcal{E}$ aduersarijs aufert; One victorie begets an other, and puts courage into those that haue alreadie had the better, taking spirit away from such as haue beene beaten.

Arrianus and Curtius make large descriptions of this battaile, fought at Gaugamela; They tell vs of many charges and re-charges; That the victorie inclined sometime to the Persians, sometime to the Macedonians; That Parmenio was in danger of being ouerthrowne, who led the left wing; That Alexanders Reare-guard was broken and his carriages lost; That for the fierce and valorous encounters on both sides, Fortune her selfe was long vnresolued on whom to bestow the Garland: And lastly, That Alexander in person wrought wonders, being charged in his retrait. But, in conclusion, Curtius deliuers vs in accompt but three hundred dead Macedonians, in all this terrible daies-worke; saying, That Ephestion, Perdiccas, and others of name, were wounded. 
Arrianus findes not a third part of this number slaine; of the Persians there fell fortie thousand (saith Curtius, thirtie thousand according to Arrianus: Ninetie thousand, if we beleeue Diodor. But what can we judge of this great encounter, other than that, as in the two former battailes, the Persians vpon the first charge ranne away, and that the Macedonians pursued? For if of these foure or fiue hundred thousand Asians brought into the field by Darius, euery man had but cast a Dart, or a Stone, the Macedonians could not haue bought the Empire of the East at so easie a rate, as sixe or seuen hundred men in three notorious battailes. Certainely, if Darius had fought with Alexander vpon the bankes of Euphrates, and had armed but fiftie or threescore thousand of this great multitude, only with Spades (for the most of all he had were fit for no other weapon) it had beene impossible for Alexander to haue past that Riuer so easily, much lesse the Riuer of Tigris. But as a man whose Empire God in his prouidence had determined, Hee abandoned all places of aduantage, and suffered Alexander to enter so far into the bowells of his Kingdome, as all hope and possibilitie of escape by retrait being taken from the Macedonians, they had presented vnto them the choise, either of death or victorie; to which election Darius could no way constraine his owne, seeing they had many large Regions to runne into from those that inuaded them.

\$I . Of thinges following the battaile of Arbela. The yeelding of Babylon and Susa.

Darivs after the rout of his Armie recouered Arbela the same night, better followed in his flight, than in the fight. He propounded vnto them that ranne after him his purpose of making a retrait into Media, perswading them that the Macedonians, greedie of spoile and riches, would rather attempt Babylon, Susa, and other Cities, filled with treasure, than pursue the vanquished. This miserable resolution his Nobilitie rather obeied than approued.

Alexander soone after Darius his departure arriues at Arbela, which with a great masse of treasure, and Princely 
ornaments, was rendred vnto him: for the feare which conducted Darius tooke nothing with it but shame and dishonour. Hee that had beene twice beaten, should rather haue sent his treasure into Media, than brought it to Arbela, so neare the place where he abid the comming of his enemies; if he had beene victorious he might haue brought it after him at leisure, but being ouer-come, hee knew it vnpossible to driue Mules and Cammels laden with gold from the pursuing Enemie, seeing himselfe, at the ouerthrow hee had in Cilicia, cast the Crowne from his head to runne away with the more speede. But errours are then best discerned when most incurable. Et praterita magis reprehendi possunt quam corrigi; It is easier to reprehend than amend what is past.

From Arbela Alexander tooke his way towards Babylon, where Mazeus in whom Darius had most confidence rendred himselfe, his children and the Citie. Also the Captaine of the Castle, who was keeper of the treasure, strewed the streetes with flowers, burnt franckinsence vpon Altars of siluer as Alexander passed by, and deliuered vnto him whatsoeuer was committed to his trust. The Magi (the Chaldean Astrologers) followed this Captain in great solemnitie to entertaine their new King: after these came the Babylonian horsemen, infinite riche in attire, but exceeding poore in warlike furniture. Betweene these (though not greatly to be feared) and himselfe, Alexander caused his Macedonian foote-men to march. When hee entred the Castle hee admired the glorie thereof, and the aboundance of treasure therein found amounting to fiftie thousand talents of siluer vncoyned. The Citie it selfe I haue elsewhere described ${ }^{I}$ with the Walles, the Towers, the Gates and the Circuite, with the wonderfull place of pleasure about two miles in Circuite, surrounded with a Wall of fourescore foote high, and on the toppe thereof (being vnderborne with Pillars) a Groue of beautifull and fruitfull trees, which it is said that one of the Kings of Babylon caused to be built, that the Queene and other Princesses might walke priuately therein. In this Citie, rich in all things but most of all in Voluptuous pleasures, the King rested himselfe and the whole Armie foure and thirtie daies, consuming that

I In III III 5-a more expansive version of the account provided here. 
time in banqueting and in all sorts of effeminate exercise, which so much softened the mindes of the Macedonians, not acquainted till now with the like delicacies, as the seuere discipline of warre which taught them the sufferances of hunger and thirst, of painefull trauaile, and hard lodging, began rather to be forgotten, than neglected.

Heere it was that those bands of a thousand Souldiers were erected, \& Commanders appointed ouer them, who thereupon were stiled Chiliarchi. This new order Alexander brought in, was to honor those Captaines which were found by certain selected Iudges to haue deserued best in the late warre. For before this time the Macedonian companies consisted but of fiue hundred. Certainely the drawing downe of the foote-bands in this latter age hath beene the cause (saith the Marshal Monluct) that the title and charge of a Captaine hath beene bestowed on euery Picque Bauf or Spurn-Cow, for when the Captaines of foote had a thousand Souldiers vnder one Ensigne, and after that fiue hundred, as in the time of Francis the first, the title was honorable and the Kings were lesse charged, and farre better serued. King Henrie the eighth of England neuer gaue the commandement of any of his good shippes, but to men of knowne valour, and of great estate, nay sometime he made two Gentlemen of qualitie commanders in one ship: but all orders and degrees are fallen from the reputation they had.

While Alexander was yet in Babylon, there came to him a great supply out of Europe, for Antipater sent him sixe thousand foote and fiue hundred horse, out of Macedon, of Thracians three thousand foote and the like number of horse, and out of Greece foure thousand foote and foure hundred horse, by which his Armie was greatly strengthned: for those that were infected with the pleasures of Babylon could hardly be brought againe, De quitter la plume pur dermir sur la dure; To change from soft beds to hard boards.

He left the Castle and Citie of Babylon with the Territories about it in charge vnto three of his owne Captaines, deliuering withall into their handes to supply al wants a thousand talents: but to grace Mazeus who rendred the citie vnto him, he gaue him the title of his Lieutenant ouer all, and SWR K 2 
tooke with him Bagislines that gaue vp the Castle, and hauing distributed to euery Souldier a part of the Treasure, he left Babylon and entred into the Prouince Satrapene: from thence he went on towards Susa in Persia, the same which Ptolomie, Herodotus, and Elianus call Memnonia, sytuate on the riuer Euleus, a Citie sometime gouerned by Daniel the prophet. Abulites also, gouernour of this famous Citie, gaue it vp to the Conquerer with fiftie thousand talents of siluer in bullion, and twelue Elephants for the warre, with all other the treasures of Darius. In this sort did those Vassalls of fortune, louers of the Kings prosperitie, not of his person (for so all ambitious men are) purchase their owne peace and safetie with the Kings treasures.

While Alexander spoiled Arbela, Mazeus might haue furnisht his owne King from Babylon, and while he staid foure and thirtie daies at Babylon, Abulites might haue holpen him from Susa: and while he feasted there, Tiridates from Persepolis might haue relieued him: for the great masse of treasure was laied vp in that Citie. But who hath sought out and friended fearefull aduersitie? It is certaine, that benefits binde not the ambitious, but the honest: for those that are but greedie of themselues, doe in all changes of fortune only studie the conseruation of their owne greatnesse.

And therefore was Alexander well aduised, that whatsoeuer titles he gaue to the Persians, yet he left all places of importance in trust with his owne Captaines, to wit, Babylon, Susa, and Persepolis, with other Cities and Prouinces by him conquered; for if Darius (as yet liuing) had beaten the Macedonians but in one battell, all the Nobilitie of Persia would haue returned to their naturall Lord. Those that are Traitors to their owne Kings are neuer to bee vsed alone in great enterprises by those Princes that entertaine them, nor euer to be trusted with the defences of any frontierTowne, or Fortresse of waight, by the rendring whereof they may redeeme their libertie and estates lost.

Hereof the French had experience, when Don Petro de Nauarra, being banished out of Spaine, was trusted with Fontarabe, in the yeare 1523 .

It is said, that Charles the fifth hauing promised Charles 
of Bourbon the gouernement of Marseilles, if he could haue forst it, and whereof he made sure accompt, told some of his nearest Counsellers, that hee meant nothing lesse than the performance of that promise, because hee should thereby haue left the Duke (reuolted from his Master) very well wherewithall to haue recouered his fauour.

The gouernement of Susa, with the Castle and Treasure, Alexander cömitted to his owne Macedonians, making Abulites who rendred it vnto him his Lieutenant, as he had done Mazeus and others, in giuing them Titles, but neither trust nor power; for he left three thousand old Souldiers in Garrison to assure the place; and Darius his Mother and her children to repose themselues.

\section{\$12. How Alexander came to Persepolis, and burnt it.}

From Susa Alexander leadeth his Armie toward Persepolis, and when he sought to passe those Mountaines which sunder Susiana and Persia, hee was soundly beaten by Ariobarzanes, who defended against him those Straights, called Pyle Persidis, or Susceide; and after the losse of many Companies of his Macedonians, he was forst to saue himselfe by retrait, causing his foote to march close together, and to couer themselues with their Targets from the stones tumbled on them from the Mountaine-top. Yet in the end he found out an other path, which a Lycian, liuing in that Countrie, discouered vnto him, and came thereby suddenly in view of Ariobarzanes, who being inforst to fight vpon euen ground, was by Alexander broken, whereupon hee fled to Persepolis, but (after that they of Persepolis had refused to receiue him) hee returned and gaue a second charge vpon the Macedonians, wherein he was slaine. In like manner did King Francis the first, in the yeare I 5 I 5 . finde a way ouer the Alpes, the Switzers vndertaking to defend all the passages, who, if their footmanship had not saued them vpon the Kings descent on the other side, they had beene ill paied for their hard lodging on those Hils.

Foure thousand Greekes, saith Curtius, (Iustine numbers them but at eight hundred) hauing beene taken prisoners 
by the Persians, presented themselues to Alexander now in sight of Persepolis. These had the barbarous Persians so maimed and defaced, by cutting off their Hands, Noses, Eares, and other Members, as they could no way haue beene knowne to their Countrie-men, but by their voices; to each of these Alexander gaue three hundred Crownes, with new garments, and such Lands as they liked to liue vpon.

Tiridates, one of Darius his false-hearted Grandes, hearing of Alexanders approch, made him know that Persepolis was readie to receiue him, and praied him to double his pace, because there was a determination in the people to spoile the Kings treasure. This Citie was abandoned by many of her Inhabitants vpon Alexanders arriuall, and they that staied followed the worst counsell, for all was left to the libertie of the Souldiers, to spoile and kill at their pleasure. There was no place in the world at that time, which, if it had beene laied in ballance with Persepolis, would haue waighed it downe. Babylon, indeede, and Susa, were very rich; but in Persepolis lay the bulke and maine store of the Persians. For after the spoile that had beene made of money, curious plate, bullion, Images of gold and siluer, and other jewells; there remained to Alexander himselfe one hundred and twentie thousand talents. He left the same number of three thousand Macedonians in Persepolis, which he had done in Susa, and gaue the same formall honour to the Traitor Tiridates, that he had done to Abulites; but he that had the trust of the place was Nicarides, a creature of his owne. The bodie of his Armie hee left here for thirtie daies, of which the Commanders were Parmenio and Craterus, and with a thousand horse and certaine troupes of chosen foote, he would needes view in the Winter-time those parts of Persia, which the Snow had couered, a fruitlesse and foolish enterprise, but as Seneca saies: Non ille ire vult, sed non potest stare; He hath not a will to goe, but he is vnable to stand still. It is said and spoken in his praise, That when his Souldiers cried out against him, because they could not indure the extreame frost, and make way, but with extreme difficultie, through the snow, that Alexander forsooke his horse, and led them the way. But what can bee more ridiculous than to 
bring other men into extreamitie, thereby to shew how well himselfe can indure it? His walking on foote did no otherwise take off their wearinesse that followed him, than his sometime forbearing to drinke did quench their thirst, that could lesse indure it. For mine owne little judgement I shall rather commend that Captaine, that makes carefull prouision for those that follow him, and that seekes wisely to preuent extreme necessitie, than those witlesse arrogant fooles, that make the vaunt of hauing indured equally with the commonSouldier, as if that were a matter of great glorie and importance.

We finde in all the Warres that Cesar made, or the best of the Roman Commanders, that the prouision of victualls was their first care. For it was a true saying of Coligni, Admirall of France; That who so will shape that beast (meaning Warre) must beginne with his bellie.

But Alexander is now returned to Persepolis, where those Historians, that were most amorous of his vertues, complaine, that the opinion of his valour, of his liberalitie, of his clemencie, towards the vanquished, and all other his Kingly conditions, were drowned in drinke; That he smothered in carrowsing cups all the reputation of his actions past, and that by descending, as it were, from the reuerend Throne of the greatest King, into the companie and familiaritie of base Harlots, he beganne to be despised both of his owne and all other Nations. For being perswaded, when he was inflamed with wine, by the infamous Strumpet Thais, he caused the most sumptuous and goodly Castle and Citie of Persepolis, to bee consumed with fire, notwithstanding all the arguments of Parmenio to the contrarie, who told him that it was a dishonour to destroy those thinges by the parswasions of others, which by his proper vertue and force he had obtained; and that it would be a most strong perswasion to the Asians, to thinke hardly of him, and thereby aliene their hearts: For they might well beleeue that hee which demolished the goodliest Ornaments they had, meant nothing lesse than (after such vastation) to hold their possession. Fere vinolentiam crudelitas sequitur; Crueltie doth commonly follow drunkennesse: For so it fell out soone after, and often, in Alexander. 
\$1 3. The Treason of Bessvs against Darivs. Darivs his death.

About this time he receiued a new supply of Souldiers out of Cilicia, and goes on to finde Darius in Media. Darius had there compounded his fourth and last Armie, which hee meant to haue increased in Bactria, had he not heard of Alexanders comming on, with whom (trusting to such companies as hee had, which was numbred at thirtie or fortie thousand) he determined once againe to trie his fortune. Hee therefore calls together his Captains and Commanders, and propounds vnto them his resolution, who being desperate of good successe vsed silence for a while. Artabazus, one of his eldest men of Warre, who had sometime liued with Philip of Macedon, brake the yce, and protesting that hee could neuer be beaten by any aduersitie of the Kings, from the faith which he had euer ought him, with firme confidence, that all the rest were of the same disposition (whereof they likewise assured Darius by the like protestation) he approued the Kings resolution. Two only, and those the greatest, to wit, Naburzanes, and Bessus, whereof the latter was Gouernour of Bactria, had conspired against their Master, and therefore aduised the King to lay a new foundation for the Warre, and to pursue it by some such person for the present, against whom neither the Gods nor Fortune had in all things declared themselues to bee an enemie: this preamble Naburzanes vsed, and in conclusion aduised the election of his fellow Traitor Bessus, with promise that, the warres ended, the Empire should againe be restored to Darius. The King swollen with disdaine prest towards Naburzanes to haue slaine him, but Bessus and the Bactrians whom he commanded, being more in number than the rest, with-held him. In the meane while Naburzanes with-drew himselfe, and Bessus followed him making their quarter a-part from the rest of the Armie. Artabazus, the Kings faithfull seruant, perswaded him to be aduised, and serue the time, seeing Alexander was at hand, and that hee would at least make shew of forgetting the offence made, which the King being of a gentle disposition willingly yeelded vnto. Bessus makes his submission and attends the King, who remoues his Armie. Patron, who commanded a Regiment of foure thou- 
sand Greekes which had in all the former battailes serued Darius with great fidelitie, and alwaies made the retrait in spight of the Macedonians, offered himselfe to guard his person, protesting against the treason of Bessus, but it was not in his destinie to follow their aduice, who from the beginning of the Warre gaue him faithfull counsell, but hee inclined still to Bessus, who told him, that the Greekes with Patron their Captaine were corrupted by Alexander, and practised the diuision of his faithfull seruants. Bessus had drawne vnto him thirtie thousand of the Armie, promising them all those thinges by which the louers of the world and themselues, are wont to be allured, to wit, riches, safetie, and honour.

Now the day following Darius plainely discouered the purposes of Bessus, and being ouer-come with passion, as thinking himselfe vnable to make head against these vngratefull and vnnaturall Traitors, he praied Artabazus his faithfull seruant to depart from him, and to prouide for himselfe. In like sort he discharged the rest of his attendants, all saue a few of his Eunuchs; for his guards had voluntarily abandoned him, His Persians being most base cowards, durst not vndertake his defence against the Bactrians, notwithstanding that they had foure thousand Greekes to joyne with him, who had beene able to haue beaten both Nations. But it is true, that him, which forsakes himselfe, no man followes. It had beene farre more manlike and King-like, to haue died in the head of those foure thousand Greekes, which offered him the disposition of their liues, (to which Artabazus perswaded him) than to haue lien bewailing himselfe on the ground, and suffering himselfe to bee bound like a slaue by those ambitious Monsters that laied hand on him, whom neither the consideration of his former great estate, nor the honors he had giuen them, nor the trust reposed in them, nor the world of benefits bestowed on them, could moue to pittie: no, nor his present aduersitie, which aboue all thinges should haue moued them, could pierce their viperous and vngratefull hearts. Vaine it was indeed to hope it, for infidelitie hath no compassion.

Now Darius, thus forsaken, was bound and laied in a Cart, couered with hides of beasts, to the end that by any 
other ornament he might not bee discouered; and to adde despight and derision to his aduersitie, they fastened him with chaines of gold, and so drew him on among their ordinarie carriages and Carts. For Bessus and Nabarzanes perswaded themselues to redeeme their liues and the Prouinces they held either by deliuering him a prisoner to Alexander, or if that hope failed, to make themselues Kings by his slaughter, and then to defend themselues by force of Armes. But they failed in both. For it was against the nature of God, who is most just, to pardon so strange villanie, yea though against a Prince purely Heathenish, and an Idolater.

Alexander hauing knowledge that Darius was retired towards Bactria, and durst not abide his comming, hasted after him with a violent speed, and because he would not force his foot-men beyond their powers, hee mounted on horse backe certaine selected Companies of them, and best armed, and with sixe thousand other Horse, rather ranne than marched after Darius. Such as hated the treason of Bessus, and secretly forsooke him, gaue knowledge to Alexander of all that had happened, informing him of the way that Bessus tooke, and how neare hee was at hand: for many men of worth daily ranne from him. Hereupon Alexander againe doubled his pace, and his Vant-guard being discouered by Bessus his reare, Bessus brought a horse to the Cart, where Darius lay bound, perswading him to mount thereon, and to saue himselfe. But the vnfortunate King refusing to follow those that had betraied him, they cast Darts at him, wounded him to death, and wounded the beasts that drew him, and slew two poore seruants that attended his person. This done, they all fled that could, leauing the rest to the mercie of the Macedonian Swords.

Polystratus a Macedonian, being by pursute of the vanquished prest with thirst, as he was refreshing himselfe with some water that he had discouered, espying a Cart with a Teame of wounded beasts breathing for life, and not able to moue, searched the same, and therein found Darius bathing in his owne bloud. And by a Persian captiue which followed this Polystratus, he vnderstood that it was Darius, and was informed of this barbarous Tragedie. Darius also seemed greatly comforted (if dying men ignorant of the liuing God 
can bee comforted) that hee cast not out his last sorrowes vnheard, but that by this Macedonian, Alexander might know and take vengeance on those Traitors, which had dealt no lesse vnworthily than cruelly with him, recommending their reuenge to Alexander by this Messenger, which hee besought him to pursue, not because Darius had desired it, but for his owne honor, and for the safetie of all that did, or should after weare Crownes. Hee also, hauing nothing else to present, rendred thankes to Alexander for the Kingly grace vsed towards his Wife, Mother, and Children, desiring the immortall Gods to submit vnto him the Empire of the whole world. As hee was thus speaking, impatient death pressing out his few remaining spirits, he desired water, which Polystratus presented him, after which he liued but to tell him, that of all the best thinges that the world had, which were lately in his power, he had nothing remaining but his last breath, where-with to desire the Gods to reward his compassion.

\$14. How Alexander pursued Bessvs, and tooke into his grace Darivs his Captaines.

It was now hoped by the Macedonians, that their trauells were neare an end, euery man preparing for his returne. Hereof when Alexander had knowledge, hee was greatly grieued; for the bounded earth sufficed not his boundlesse ambition. Many arguments hee therefore vsed to draw on his Armie farther into the East, but that which had most strength was, that Bessus, a most cruell Traitor to his Master Darius, hauing at his deuotion the Hyrcanians, and Bactrians, would in short time (if the Macedonians should returne) make himselfe Lord of the Persian Empire, and enjoy the fruits of all their former trauailes. In conclusion, hee wanne their consents to goe on: which done, leauing Craterus with certaine Regiments of foot, and Amyntas with sixe thousand Horse in Parthenia, hee enters not without some opposition into Hyrcania; for the Mardons, and other barbarous Nations, defended certaine passages for a while. Hee passeth the Riuer of Zioberis, which taking beginning 
in Parthia dissolues it selfe in the Caspian Sea: it runneth vnder the ledge of Mountaines, which bound Parthia and Hyrcania, where hiding it selfe vnderground for three hundred furlongs, it then riseth againe and followeth its former course. In Zadracarta or Zeudracarta, the same Citie which Ptolomie writes Hyrcania, the Metropolis of that Region, hee rested fifteene daies, banquetting, and feasting therein.

Phataphernes, one of Darius his greatest Cömanders, with other of his best followers, submit themselues to Alexander, and were restored to their places and gouernements. But of all other he graced Artabazus most highly for his approued \& constant faith to his Master Darius. Artabazus brought with him ten thousand and fiue hundred Greekes, the remainder of all those that had serued Darius; He treats 'with Alexander for their pardon, before they were yet arriued, but in the end they render themselues simply without promise or composition: he pardons all but the Lacedemonians, whom he imprisoned, their Leader hauing slaine himselfe. Hee was also wrought; (though to his great dishonour) to receiue Nabarzanes that had joyned with Bessus to murder Darius.

\$I 5. Of Thalestris Queene of the Amazons; where, by way of digression it is shewed, that such Amazons haue beene, and are.

Here it is said; that Thalestris or Minothea, a Queene of the Amazones, came to visite him, and her sute was, (which shee easily obtayned) That shee might accompanie him till shee were made with child by him: which done (refusing to follow him into India) shee returned into her owne Countrie.

Plutarch citeth many Historians, reporting this meeting of Thalestris with Alexander, and some contradicting it. But, indeede, the letters of Alexander himselfe to Antipater, recounting all that befell him in those parts, and yet omitting to make mention of this Amazonian businesse, may justly breede suspition of the whole matter as forged. Much more justly may we suspect it as a vaine tale, because an Historian of the same time reading one of his bookes to Lysimachus 
(then King of Thrace) who had followed Alexander in all his voiage; was laught at by the King for inserting such newes of the Amazons, as Lysimachus himselfe had neuer heard of. One that accompanied Alexander tooke vpon him to write his acts; which to amplifie, He told how the King had fought single with an Elephant, and slaine it. The King hearing such stuffe, caught the booke, and threw it into the Riuer of Indus; saying, that it were well done to throw the writer after it, who by inserting such fables disparaged the truth of his great exploits. Yet as wee beleeue and know that there are Elephants, though it were false that Alexander fought with one; so may we giue credit vnto writers, making mention of such Amazons, whether it were true or false that they met with Alexander; as Plutarch leaues the matter vndetermined. Therefore I will here take leaue to make digression, as well to shew the opinions of the ancient Historians, Cosmographers, and others, as also of some moderne discouerers touching these warlike Women, because not only Strabo, but many others of these our times make doubt, whether, or no, there were any such kinde of people. Iulius Solinus seates them in the North parts of Asia the lesse. Pom. Mela finds two Regions filled with them; the one, on the Riuer Thermodoon; the other, neare the Caspian Sea; Quas (saith hee) Sauromatidas appellant; Which the people call Sauromatidas. The former of these two had the Cimerians for their Neighbours; Certum est (saith Vadianus, who hath Commented vpon Mela) illos proximos Amazonibus fuisse; It is certaine that the Cimerians were the next Nations to the Amazones. Ptolomie sets them farther into the Land North-wards, neare the Mountaines Hippaci, not farre from the Pillars of Alexander. And that they had Dominion in Asia it selfe toward India, Solinus and Plinie tells vs; Where they gouerned a people called the Pandeans, or Padeans, so called after Pandea the Daughter of Hercules, from whom all the rest deriue themselues. Claudian affirmes, That they commanded many Nations: For he speakes (largely perhaps as a Poet) thus.

Medis leuibusque Sabais

Imperat hic fexus: Reginarumque sub armis,

Barbarice pars magna iacet. 
Ouer the Medes, and light Sabæans, raignes This female sexe: and vnder armes of Queene[s], Great part of the Barbarian Land remaines. ${ }^{\mathrm{I}}$

Diodorus Siculus hath heard of them in Lybia, who were more ancient (saith hee) than those which kept the bankes of Thermodoon, a Riuer falling into the Euxine Sea neare Heraclium.

Herodotus doth also make report of these Amazons, whom hee tells vs that the Scythians call Eorpatas, which is as much as Viricidas, or Men-killers. And that they made incursion into Asia lesse, sackt Ephesus, and burnt the Temple of Diana, Manethon and Auentinus report, which they performed fortie yeares after Troy was taken. At the siege of Troy it selfe wee read of Penthesilea, That shee came to the succour of Priamus.

Am. Marcellinus giues the cause of their inhabiting vpon the riuer of Thermodoon, speaking confidently of the Warres they made with diuers Nations, and of their ouerthrow.

Plutarch in the life of Theseus, out of Philochorus, Hellanicus, and other ancient Historians, reports the taking of Antiopa Queene of the Amazons by Hercules, and by him giuen to Theseus, though some affirme, That Theseus himselfe got her by stealth when shee came to visit him aboord his ship. But in substance there is little difference; all confessing, That such Amazons there were. The same Author in the life of Pompey speakes of certaine companies of the Amazons, that came to aide the Albanians against the Romans, by whom, after the battaile, many Targets and Buskins of theirs were taken vp: and he saith farther, That these women entertaine the Gele and Lelages once a yeare, Nations inhabiting betweene them and the Albanians.

But to omit the many Authors, making mention of Amazons that were in the old times, Fran. Lopez who hath written the nauigation of Orellana, which he made down the Riuer of Amazons from Peru, in the yeare I 542. (vpon which Riuer, for the diuers turnings, he is said to haue sailed sixe thousand miles) reports from the relation of the said Orellana, to the Councell of the Indies, That hee both

I Claudian, In Eutropium, I $32 \mathrm{I}-3$. 
saw those women and fought with them, where they sought to impeach his passage towards the East-Sea.

It is also reported by Vlricus Schmidel, that in the yeare I 542. where he sailed vp the Riuers of Paragna and Parabol, that he came to a King of that Countrie, called Scherues, inhabiting vnder the Tropick of Capricorne, who gaue his Captaine Ernando Rieffere, a Crowne of siluer, which hee had gotten in fight from a Queene of the Amazons in those parts.

Ed. Lopes, in his description of the Kingdome of Congo, makes relation of such Amazons, telling vs, That (agreeable to the reports of elder times) they burne off their right breast, and liue a-part from men, saue at one time of the yeare, when they feast and accompanie them for one moneth. These (saith he) possesse a part of the Kingdome of Monomotapa in Africa, nineteene degrees to the Southward of the line: and that these women are the strongest guards of this Emperour, all the East Indian Portugals know.

I haue produced these authorities, in part, to iustifie mine owne relation of these Amazons, because that which was deliuered mee for truth by an ancient Casique ${ }^{\mathrm{I}}$ of Guiana, how vpon the Riuer of Papamena (since the Spanish discoueries called Amazons) that these women still liue and gouerne, was held for a vaine and vnprobable report.

\$16. How Alexander fell into the Persians Luxurie: and how hee further pursued Bessvs.

Now as Alexander had begunne to change his conditions after the taking of Persepolis: so at this time his prosperitie had so much ouer-wrought his vertue, as he accompted clemencie to bee but basenesse, and the temperance which he had vsed all his life-time, but a poore and dejected humor, rather becomming the instructers of his youth, than the condition and state of so mightie a King, as the world could not equall. For he perswaded himselfe that he now represented the greatnesse of the Gods; hee was pleased that those

I Native chief or 'prince'. 
that came before him, should fall to the ground and adore him; hee ware the Robes, and garments of the Persians, and commanded that his Nobilitie should doe the like; hee entertained in his Court, and Campe, the same shamelesse rabble of Curtisans, and Sodomiticall Eunuchs, that Darius had done, and imitated in all thinges the proude, voluptuous, and detested manners of the Persians, whom he had vanquished. So licentious is felicitie, as notwithstanding that he was fully perswaded, that the Gods, whom he serued (detesting the vices of the inuaded) assisted him in all attempts against them, he himselfe contrarie to the religion he profest (which how Idolatrous soeuer it were, could not bee but fearefull vnto him by neglecting it) became by imitation, and not by ignorance or education, a more foule and fearefull Monster than Darius, from whose tyrannie he vaunted to haue deliuered so many Nations. Yea those that were dearest and nearest vnto him, began to be ashamed of him, entertaining each other with this, and the like scornefull discourse, That Alexander of Macedon was become one of Darius his licentious Courtiers; That by his example the Macedonians were in the end of so many trauailes more impouerished in their vertues, than inriched by their victories; and that it was hard to judge whether the Conquerors, or the conquered were the baser slaues. Neither were these opinions so reserued, but that the noise of them came to his eares. He therefore with great gifts sought to pacifie the better sort, and those of whose judgements he was most jealous; and making it knowne to the Armie that Bessus had assumed the title of a King, and called himselfe Artaxerxes, and that hee had compounded a great Armie of the Bactrians, and other Nations, hee had arguments enough to perswade them to goe on, to the end that all alreadie gotten, might not with themselues (so farre ingaged) be cast away. And because they were pestered with the spoiles of so many Cities, as the whole Armie seemed but the guard of their carriages, (not much vnlike the warfare of the French) hauing commanded euery mans fardells to be brought into the market-place, he together with his owne, caused all to bee consumed with fire. Certainely, this could not but haue proued most dangerous vnto him, seeing the common- 
Souldiers had more interest in these thinges, which they had bought with their painefull trauailes, and with their bloud; than in the Kings ambition; had not (as Seneca often obserued) his happie temeritie ouer-come all thinges. As he was in his way, newes came to him that Satribarzanes, whom he had established in his former gouernement ouer the Arrians, was reuolted, whereupon leauing the way of Bactria, he sought him out, but the Rebelle hearing of his comming fled to Bessus with two thousand Horse. Hee then went on towards Bessus, and by setting a great pile of wood on fire with the aduantage of a strong winde, wonne a passage ouer a high and vnaccessable Rock, which was defended against him with thirteene thousand foote. For the extremitie of the flame and smoke forced them from the place, otherwise inuincible. I saw in the third ciuill Warre of France certaine caues in Languedoc, which had but one entrance, and that very narrow, cut out in the mid-way of high Rocks, which we knew not how to enter by any ladder or engine, till at last by certaine bundells of straw let downe by an yron chaine, and a waightie stone in the middest, those that defended it were so smothered, as they rendred themselues with their plate, monie, and other goods therein hidden. There were also, some three yeares before my arriuall in Guiana, three hundred Spaniards well mounted, smothered to death, together with their Horses, by the Countrie people, who did set the long drie-grasse on fire to the eastward of them, (the winde in those parts being alwaies East) so as notwithstanding their flying from the smoke, there was not any one that escaped. Sr Iohn Borrowes also, with a hundred English, was in great danger of being lost at Margarita, in the West-Indies, by hauing the grasse fired behinde him, but the smoke being timefully discouered, hee recouered the Sea-shore with the losse of sixteene of his men. I remember these thinges, but to giue caution to those that shall in times to come inuade any part of those Countries, that they alwaies, before they passe into the Land, burne downe the grasse and sedge to the East of them; they may otherwise, without any other enemie than a handfull of straw set on fire, die the death of honnie-Bees, burnt out of the Hiue. 
\$17. A conspiracie against Alexander. The death of Philotas and Parmenio.

Alexander was after he parted hence no where resisted, till he came into Asia, to the East of Bactria, where the chiefe Citie of that Prouince, called Artacoana, was a while defended against him, by the reuolt of Sartibarzanes, but in the end hee receiued the Inhabitants to mercie. At this place his Armie was re-enforced with a new supply of fiue thousand and fiue hundred foote, and neare fiue hundred Horse, out of Greece, Thessalie, and other places. His journie out of Persia into these parts is very confusedly described. For hauing (as all his Historians tell vs) a determination to finde Bessus in Bactria, he leaues it at the very entrance, and takes the way of Hyrcania; from thence hee wanders Northward towards the obscure Mardi, vpon the Caspian-Sea, and thence ouer the Mountaines Coronus into Aria, and Drangiana.

At this time it was that the treason of Dimnus brake out, of which Philotas the sonne of Parmenio was accused, as accessarie, if not principall. This Dimnus, hauing (I know not vpon what ground) conspired with some others against the life of Alexander, went about to draw Nicomachus, a yong-man whom he loued, into the same treason. The youth, although he was first bound by oath to secrecie, when he heard so foule a matter vttered, beganne to protest against it so vehemently, that his friend was like to haue slaine him for securitie of his owne life. So constrained by feare, hee made shew as if hee had beene wonne by perswasion, and by seeming at length to like well of the businesse, hee was told more at large what they were, that had vndertaken it. There were nine or ten of them, all men of ranke; whose names Dimnus (to countenance the enterprise) reckoned vp to Nicomachus. Nicomachus had no sooner freed himselfe from the companie of this Traitor Dimnus, than he acquainted his owne brother Ceballinus with the whole Historie: whereupon it was agreed betweene them, that Ceballinus (who might with least suspition) should goe to the Court and vtter all. Ceballinus, meeting with Philotas, told him the whole businesse; desiring him to acquaint the King therewith: which hee promised to doe, but did not. Two daies passed, and 
Philotas neuer brake with the King about the matter; but still excused himselfe to Ceballinus by the Kings want of leisure. This his coldnesse bred suspition, and caused Ceballinus to addresse himselfe to another, one Metron, keeper of the Kings Armorie, who forth-with brought him to Alexanders presence. Alexander, finding by examination what had passed betweene Ceballinus and Philotas, did fully perswade himselfe that this concealement of the treason argued his hand to haue beene in the businesse. Therefore when Dimnus was brought before him, he asked the Traitor no other question than this: Wherein haue I so offended thee, that thou shouldest thinke Philotas more worthie to be King than I? Dimnus perceiuing, when he was apprehended, how the matter went, had so wounded himselfe that hee liued no longer than to giue his last groane in the Kings presence. Then was Philotas called, and charged with the suspition which his silence might justly breede. His answere was, That when the practise was reuealed vnto him by Nicomachus, he judging it to be but friuolous, did forbeare to acquaint Alexander therewithall, vntill he might haue better information. This errour of his, (if it were only an errour) although Alexander, for the notorious seruices of his Father Parmenio, of his brother Nicanor lately dead, and of Philotas himselfe, had freely pardoned and giuen him his hand for assurance; yet by the instigation of Craterus, hee againe swallowed his Princely promise, and made his enemies his Iudges: Curtius giues a note of Craterus in this businesse; How hee perswaded himselfe, that he could neuer finde a better occasion to oppresse his priuate enemie, than by pretending pietie and dutie towards the King. Hereof a Poet of our owne hath given a note as much better as it is more generall in his Philotas.

See how these great men cloathe their priuate hate,

In these faire colours of the publike good, And to effect their ends, pretend the State, As if the State by their affection stood, And arm'd with power and Princes jealousies,

Will put the least conceit of discontent

Into the greatest ranke of treacheries,

That no one action shall seeme innocent; 
Yea valour, honour, bountie, shall be made

As accessaries vnto ends vnjust:

And euen the seruice of the State must lade

The needfull'st vndertaking with distrust,

So that base vilenesse, idle Luxurie,

Seeme safer farre, than to doe worthily, \&c.I

Now although it were so that the King, following the aduise of Craterus, had resolued the next day to put Philotas to torment, yet in the very euening of the same night in which he was apprehended, he called him to a banquet, and discoursed as familiarly with him as at any other time. But when in the dead of the night Philotas was taken in his lodging, and that they which hated him beganne to binde him; he cried out vpon the King in these wordes: $O$ Alexander, the malice of mine Enemies hath surmounted thy mercie, and their hatred is farre more constant than the word of a King. Many circumstances were vrged against him by Alexander himselfe; (for the Kings of Macedon did in person examine the accusations of treason) and this was not the least (not the least offence, indeede, against the Kings humour, who desired to be glorified as a God) That when Alexander wrote vnto him concerning the title giuen him by Iupiter Hammon; He answered, That he could not but rejoyce that he was admitted into that sacred Fellowship of the Gods, and yet hee could not but withall grieue for those that should liue vnder such a one as would exceede the nature of man. This was (saith Alexander) a firme perswasion vnto me, that his heart was changed, and that hee held my glorie in despight. See what a strange Monster flatterie is, that can perswade Kings to kill those that doe not praise and allow those thinges in them, which are of all other most to be abhorred. Philotas was brought before the multitude to heare the Kings Oration against him: he was brought forth in vilde garments, and bound like a Theefe; where hee heard himselfe, and his absent Father the greatest Captaine of the World, accused, his two other Brothers Hector and Nicanor hauing beene lost in the present Warre. Hee was

I Samuel Daniel, The Tragedie of Philotas (1607), sig. Bro [Act III, Chorus, I-I4]. This is Ralegh's most extensive quotation from any contemporary poet. 
so greatly opprest with griefe as for a while he could vtter nothing but teares, and sorrow had so wasted his spirits as hee sunke vnder those that led him. In the end the King asked him in what language he would make his defence; he answered, In the same wherein it had pleased the King to accuse him, which hee did to the end that the Persians, as well as the Macedonians, might vnderstand him. But hereof the King made his aduantage, perswading the assembly that hee disdained the language of his owne Countrie, and so with-drawing himselfe, left him to his mercilesse enemies.

This proceeding of the Kings, Philotas greatly lamented, seeing the King who had so sharply inuaied against him, would not vouchsafe to heare his excuse. For, not his enemies only were imboldened thereby against him, but all the rest hauing discouered the Kings disposition and resolution, contended among themselues which of them should exceede in hatred towards him; Among many other arguments which he vsed in his owne defence, this was not the weakest, That when Nicomachus desired to know of Dimnus what men of marke and power were his partners in the conspiracie (as seeming vnwilling to aduenture himselfe with meane and base Companions) Dimnus named vnto him Demetrius of the Kings Chamber, Nicanor, Amyntas, and some others, but spake not a word of Philotas, who by being commander of the Horse, would greatly haue valued the partie, and haue incouraged Nicomachus. Indeede, as Philotas said well for himselfe, it is likely that Dimnus, thereby the better to haue heartned Nicomachus, would haue named him, though hee had neuer dealt with him in any such practise. And for more certaine proofe that he knew nothing of their intents, that practised against the King, there was not any one of the Conspirators, being many, inforst by torments or otherwise, that could accuse him, and it is true, that aduersitie being seldome able to beare her owne burden, is for the most part found so malicious, as shee rather desires to draw others (not alwaies deseruing it) into the same danger than to spare any that it can accuse. Yet at the last, howsoeuer it were, to auoide the extremitie of resistelesse and vnnaturall torments, deuised by his profest enemies Craterus, Cenus, Ephestion, and others, Philotas accused his owne selfe; 
being perswaded that they would haue slaine him forthwith. But he failed euen in that miserable hope, and suffering all that could be laied on flesh and bloud, he was forst to deliuer, not what he knew, but whatsoeuer best pleased their eares, that were farre more mercilesse than death it selfe.

Of this kinde of judiciall proceeding St. Augustine greatly complaineth as a matter to bee bewailed, saith hee, with Fountaines of teares. ... What shall we say to it, when one is put to torture in his owne case; and tormented whilest yet it is in question whether he be guiltie; and being innocent suffers assured punishment for a fault of which there is no certaintie, not because he is knowne to haue committed the offence, but because others doe not know that he hath not committed it.

It had beene enough for Alexanders safetie if Philotas had been put to death without torment, the rest would not much haue grieued thereat, because he was greatly suspected. But Hemolaus, who afterward conspired against him, made the Kings crueltie and delight in bloud the greatest motiue of his owne ill intent. Therefore, Seneca speaking of Alexander, saith thus: . . Crueltie is not a humane vice; it is vnworthie of so mild a spirit. It is euen a beastly rage to delight in bloud and wounds, and casting away the nature of man to become a sauage Monster.

For the conclusion of this Tragedie, Curtius makes a doubt, whether the confession that Philotas made were to giue end to the torments which hee could not any longer indure, or that the same was true indeede; For (saith he) in this case, they that speake truely, or they that denie falsly, come to one and the same end. Now while the Kings hands were yet wet in bloud, he commanded that Lyncestes, sonne-inLaw to Antipater, who had beene three yeares in prison, should bee slaine: The same dispatch had all those that Nicomachus had accused: others there were that were suspected, because they had followed Philotas, but when they had answered for themselues that they knew no way so direct to winne the Kings fauour, as by louing those whom the King fauoured; they were dismist. But Parmenio was yet liuing; Parmenio, who had serued with great fidelitie as well Philip of Macedon the Kings Father, as himselfe; Parmenio that first opened the way into Asia; That had 
deprest Attalus the Kings enemie; that had alwaies, and in all hazards, the leading of the Kings Vant-guard, that was no lesse prudent in counsell, than fortunate in all attempts; A man beloued of the men of Warre, and, to say the truth, hee that had made the purchase for the King of the Empire of the East, and of all the glorie and fame he had: That he might not therefore reuenge the death of his Sonne, though not vpon the King, (for it was vnlikely that he would haue dishonoured his fidelitie in his eldest age, hauing now liued threescore and ten yeares) yet vpon those that by the witchcraft of flatterie had possest themselues of his affection; it was resolued that he should be dispatcht. Polydamas was imploied in this businesse, a man whom of all other Parmenio trusted most, and loued best, who (to be short) finding him in Media, and hauing Cleander and other Murderers with him, slew him walking in his Garden, while he was reading the Kings letters. Hic exitus Parmenionis fuit, militice domique clari viri; Multa sine Rege prosperè, Rex sine illo nihil magne rei gesserat; This was the end of Parmenio (saith Cvrtivs) who had performed many notable thinges without the King, but the King, without him, did neuer effect any thing worthie of praise.

\$18. How Alexander subdued the Bactrians, Sogdians, and other people. How Bessvs was deliuered into his hands. How he fought with the Scythians.

When these things had end, Alexander went on with his Armie, and brought vnder his obedience the Araspians or Euergitans; he made Amenides (sometime Darius his Secretarie) their Gouernour; then he subdued the Arachosians, and left Menon to commaund ouer them. Heere the Armie, sometimes led by Parmenio, findes him, consisting of twelue thousand Macedons and Greekes, with whom he past through some colde regions with difficultie enough. At length hee came to the foote of the Mountaine Taurus towards the East, where he built a Citie which he honoured with his owne name, and peopled with seuen thousand of his olde Macedons, worne with age and with trauailes of the warre. 
Traitor into the hands of Oxatres, Darius his brother, to be tormented.

But while he now thought himselfe secure, some twentie thousand Mountainers assalted his Camp; in repelling whom he receiued a shot in the leg, the arrow-head sticking in the flesh, so as he was carried in a Horse-Lytter, sometime by the horsemen, sometime by the foote.

Soone after he came vnto Maracanda, which Petrus Perondinus takes to be Samarchand, the regall Citie of the great Tamerlaine. It had in compasse threescore and ten furlongs (Curtius saith). Heere hee receiued the Embassadors of the Scythians (called Auians) who offered to serue him.

The Bactrians are shortly againe with the Sogdians stirred to Rebellion by the same Spitamenes and Catanes who had lately deliuered into his hands the Traitor Bessus. Many Cities were resoluedly defended against him, all which, after victorie, hee defaced and rased, killing all therein. At one of these hee receiued a blow on the neck which strucke him to the ground, and much disabled him for many daies after. In the meane while Spitamenes had recouered Maracanda, against whom he imployed Menedemus with three thousand foote and eight hundred horse.

In the heate of these tumults Alexander marched on (if we may beleeue Curtius and others) till he came to the Riuer of Tanais; vpon whose banke he built another Alexandria threescore furlongs in compasse, which he beautified with houses within seuenteen daies after the walls built. The building of this Citie is said to haue bin occasion of a war betweene him and the Scythians; the Scythian King perswading himselfe, that this new Towne was fortified of purpose to keepe him vnder. I doe not well vnderstand, why the Scythians, offering warre in such terrible manner that Alexander was iudged by his owne Souldiers to counterfeit sicknesse for verie feare, should neuerthelesse make suit for peace: neither finde I the reason why Alexander (not intending the conquest of those Northerne deserts, but only the defense of his owne banke) should refuse to let them alone, with whom he could not meddle further than they should agree to suffer him. Yet hereof is made a great matter; and a victorie described; in pursuit of which the 
Macedons ranne beyond the boundes and monuments of Bacchus his expedition.

The truth is, That Curtius and Trogus haue greatly mistaken this Riuer which they call Tanais. For it was the Riuer of Iaxartes, that runnes betweene Sogdiana and Scythia, which Alexander past ouer, while Menedemus was imploied in the recouery of Samarchand: But Tanais which diuides Asia from Europe is neere two thousand miles distant from any part of Bactria or Sogdiana, and the way desert and vnknowne. So that Alexander had (besides Iaxartes) the great Riuer of $V o l g a$ and manie others to swimme ouer, ere hee could recouer Tanais; which (from the place where he was) he could hardly haue discouered with the Armie that followed him, if he had imploied all the time that he liued in Asia in that trauaile.

Wherefore it is enough to beleeue, that the Asiatique Scythians, making some offer to disturbe the erection of this new Citie, which was like to giue some hindrance to their excursions, were driuen away by the Macedonians; and being naked of defensiue Armes, easily chased some tenne or twelue miles; which is the substance of Curtius his report. As for the limits of Bacchus his iournie; like enough it is that Bacchus (if in his life time he were as sober a man, as after his death he was held a drunken God) went not verie farre into that wast Countrie, where hee could finde nothing but trees and stones, nor other busines than to set vp a monument.

Threescore of the Macedons are said to haue beene slaine, and one thousand one hundred hurt in this fight, which might easily be, in passing a great Riuer, defended against them by good Archers. Of Scythian horses one thousand eight hundred were brought into the Campe, and many prisoners. It is forbidden by some Historians, and indeed it is hardly possible, to set downe the numbers of such as perish in battell: yet Cesar commonly did it. And where the diligence of the victors hath beene so inquisitiue into the greatnesse of their owne successe, that writers haue beene able to deliuer such particulars by credible reporte, I hold it not vnlawfull to set downe what we finde; especially when it serues to giue light to the businesse in hand. The small 
number which the Macedonians lost; the omission of the number which they slew (a thing not vsuall in Curtius, who forbeares nothing that may set out the greatnesse of Alexander) and the little bootie that was gotten; doe make it probable, that this warre was no better than the repulsion of a few rouing Tartars (the like being yearely performed by the Moscouite, without any boast) and therefore better omitted by some Historians, than so highly extolled as a great exploit by others.

While Alexander was assuring himselfe of those Scythians bordering vpon Iaxartes, he receiued the ill newes that Menedemus was slaine by Spitamenes, the Armie (by him led) broken, and the greatest numbers slaine, to wit, two thousand foote, and three hundred horse. $\mathrm{He}$ therefore, to appease the rebellion and to take reuenge of Spitamenes, makes all the hast he can; but Spitamenes flies into Bactria. Alexander kills, burnes, and laies wast all before him; not sparing the innocent children, and so departs, leauing a new Gouernour in that Prouince.

To repaire this losse he receiued a great supply of nineteene thousand Souldiers out of Greece, Lycia, and Syria; with all which, and the old Armie, hee returnes towards the South, and passeth the Riuer of Oxus; on the South-side whereof hee built sixe Townes neare each other for mutuall succour. But hee finds a new start-vp-Rebell, called Arimazes (a Sogdian) followed with thirtie thousand Souldiers that defended against him a strong peece of ground on the top of a high Hill; whom when Alexander had sought in vaine to winne by faire words, hee made choise of three hundred yong-men, and promised ten talents to the first, nine to the second, and so in proportion to the rest, that could finde a way to creepe vp to the top thereof. This they performed with the losse of some two and thirtie of their men, and then made a signe to Alexander, that they had performed his commandement. Hereupon he sent one Cophes to perswade Arimazes to yeeld the place; who, being shewed by Cophes that the Armie of Macedon was alreadie mounted vp, yeelded simply to Alexanders mercie, and was (with all his kindred) scourged and crucified to death; which punishment they well deserued for neglecting to keepe good watch in so SWR L 
dangerous a time. For the place, as seemes by the description, might easily haue beene defended against all the Armies of the World. But, what strength cannot doe; Mans wit, being the most forcible engine, hath often effected; Of which I will giue you an example in a place of our owne.

The Iland of Sarke, joyning to Garnsey and of that gouernement, was in Queene Maries time surprised by the French, and could neuer haue beene recouered againe by strong hand, hauing cattle and corne enough vpon the place to feede so many men as will serue to defend it, and being euery way so inaccessible that it might bee held against the Great Turke. Yet by the industrie of a Gentleman of the Netherlands, it was in this sort regained. Hee anchored in the roade with one ship of small burden, and, pretending the death of his Marchant, besought the French, being some thirtie in number, that they might burie their Marchant in hallowed ground, and in the Chappell of that Isle; offering a present to the French of such commodities as they had aboord; whereto (with condition that they should not come a-shore with any weapon, no not so much as with a knife) the French-men yeelded. Then did the Flemings put a Coffin into their boat, not filled with a dead carkasse, but with Swords, Targets, and Harquebusses; The French receiued them at their landing; and searching euery of them so narrowly as they could not hide a pen-knife, gaue them leaue to draw their Coffin vp the Rocks with great difficultie; some part of the French tooke the Flemish boat and rowed aboord their ship, to fetch the commodities promised, and what-else they pleased, but being entred they were taken and bound. The Flemings on the Land, when they had carried their Coffin into the Chappell, shut the dore to them, and taking their weapons out of the Coffin set vppon the French; they runne to the Cliffe and crie to their companie aboord the Fleming to come to their succour, but finding the boat charged with Flemings yeelded themselues and the place. Thus a Foxe-taile doth sometimes helpe well to peece out the Lions-skinne, that else would be too short. 
\$19. How Alexander slew his owne friends.

After these Sogdian and Scythian Warres, wee reade of Alexanders killing of a Lion, and other friuolous matter, and that he committed the gouernement of Maracanda, and the Countrie about it, to Clytus, and how he slew him soone after, for valuing the vertue of Philip the father before that of Alexander the sonne, or rather because hee objected to the King the death of Parmenio, and derided the Oracle of Hammon: for therein he toucht him to the quick, the same being deliuered in publike and at a drunken banquet. Clytus, indeede, had deserued as much at the Kings hands, as any man liuing had done, and had in particular saued his life, which the King well remembred when he came to himselfe, and when it was too late. Yet to say the truth, Clytus his insolencie was intolerable. As he in his cups forgat whom hee offended, so the King in his (for neither of them were themselues) forgat whom he went about to slay, for the griefe whereof he tare his owne face and sorrowed so inordinately, as, but for the perswasions of Calisthenes, it is thought he would haue slaine himselfe.

Wine begat furie, furie matter of repentance: but præceding mischiefs are not amended by succeeding bewailings.... Drunkennesse both kindles and laies open euery vice; it remoues out of the way that shame which giues impediment vnto bad attempts; where wine gets the mastrie, all the ill that before lay hidden breakes out: drunkennesse indeede rather discouers vices, than makes them.

Soone after this, Spitamenes, who slew Bessus, and had lately reuolted from Alexander, was murdered by his Wife, and his head presented to Alexander. Spitamenes being taken away, the Dahans also seized vpon his fellow-conspirator Dataphernes, and deliuered him vp. So Alexander being now freed from all these pettie-rebels, disposed of the Prouinces which he past ouer, and went on with his Armie into Gabaza, where it suffered so much Hunger, Cold, Lightning, Thunder, and Storme, as he lost in one Tempest a thousand of his traine. From hence hee inuaded the Sacans, and destroied their Countrie. Then came he into the Territorie of Cohortanes who submitted himselfe vnto him, feasted him 
greatly, and presented him with thirtie beautifull Virgins, among whom Roxane, afterward his Wife, was one: which although all the Macedonians disdained, yet none of them durst vse any freedome of speech after Clytus his death. From hence hee directed his course towards India, hauing so increased his numbers, as they amounted to an hundred and twentie thousand armed men.

In the meane while hee would needes bee honoured as a God: whereto that hee might allure the Macedonians, hee imploied two pernitious Parasites, Hagis and Cleo; whom Calisthenes opposed: For, among many other honest arguments vsed to the assembly, he told Cleo, That he thought that Alexander would disdaine the gift of God-head from his Vassalls; That the opinion of Sanctitie, though it did sometime follow the death of those who in their life-time had done the greatest thinges, yet it neuer accompanied any one as yet liuing in the World. He further told him, That neither Hercules nor Bacchus were Deified at a banquet, and vpon drinke, (for this matter was propounded by Cleo at a carowsing feast) but that, for the more than manly acts by them performed while they liued, they were in future and succeeding Ages numbred among the Gods. Alexander stood behinde a partition and heard all that was spoken, waiting but an opportunitie to bee reuenged on Calisthenes, who being a man of free speech, honest, learned, and a louer of the Kings honour, was yet soone after tormented to death, not for that hee had betraied the King to others, but because hee neuer would condescend to betray the King to himselfe, as all his detestable flatterers did. For in a conspiracie against the King made by one Hermolaus and others (which they confest) he caused Callisthenes without confession, accusation, or triall, to be torne a-sunder vpon the rack: This deede, vnworthie of a King, Seneca thus censureth. ... This is the eternall crime of Alexander, which no vertue nor felicitie of his in $W$ arre shall euer be able to redeeme. For as of ten as any man shall say, He slew many thousand Persians; it shall be replied, $\mathrm{He}$ did so, and he slew Callisthenes: When it shall be said, He slew Darivs, it shall be replied, and Callisthenes; When it shall be said, he wanne all as farre as to the very Ocean, thereon also he aduentured with vnusuall Nauies; and extended his 
Empire from a corner of Thrace, to the vtmost bounds of the Orient, It shall be said with all; But he killed Callisthenes. Let him haue out-gone all the ancient examples of Captaines and Kings; none of all his acts makes so much to his glorie, as Callisthenes to his reproach.

\$20. Of Alexanders iournie into India. The battaile betweene him and Porvs.

With the Armie before remembred, of one hundred and twentie thousand foot and horse, Alexander did enter the borders of India, where such of the Princes, as submitted themselues vnto him, he entertayned louingly, the rest hee constrained; killing Man, Woman, and Child, where they resisted. Hee then came before Nisa built by Bacchus, which after a few daies was rendred vnto him. From thence he remoued to a Hill at hand, which on the top had goodly Gardens filled with delicate fruits and Vines, dedicated to Bacchus, to whom hee made feasts for ten daies together. Now when hee had drunke his fill, hee went on towards Dedala, and thence to Acadera, Countries spoiled and abandoned by the Inhabitants, by reason whereof, victualls failing, he diuides his Armie: Ptolomie led one part, Cenon an other, and himselfe the rest. They take many Townes, whereof that of greatest fame was Mazage, which had in it three hundred thousand men; but after some resistance, it was yeelded vnto him by Cleophe the Queene, to whom againe he restored it; at the siege of this Citie he receiued a wound in the legge. After this, Nora was taken by Polysperchon, and a Rock of great strength by himselfe: he wanne also a passage vpon one Eryx, who was slaine by his companie, and his head presented to Alexander. This is the summe of Alexanders doings in those parts, before such time as hee arriued at the Riuer of Indus. Comming to Indus hee found there Ephestion, who (being sent before) had prepared boates for the transportation of his Armie, and ere Alexanders arriuall, had perswaded Omphis King of that part of the Countrie to submit himselfe to this great Conquerour. Therefore, soone vpon Alexanders comming, Omphis 
presented himselfe with all the strength of his Countrie, and sixe and fiftie Elephants, vnto him; offering him his seruice and assistance. Hee made Alexander know that hee was an Enemie to the next two great Kings of that part of India, named Abiasares and Porus; wherewith Alexander was not a little pleased, hoping by this disvnion to make his owne victorie by farre the more easie. Hee presented Alexander with a Crowne of gold, so did he the rest of his Commanders, and withall fourescore talents of siluer coine, which Alexander not only refused, but to shew that he was couetous of glorie, not of gold, he gaue Omphis a thousand talents of his owne treasure, besides other Persian rarities. Abiasares, hauing heard that Alexander had receiued his enemie Omphis into his protection, resolued to make his owne peace also: For, knowing that his owne strength did but equall that of Omphis, and that there was no other difference betweene them, than that which the chance of Warre gaue, hee thought it an ill match when Alexander, who had alreadie beaten vnder foote all the greatest Princes of Asia, should make himselfe a Partie and Head of the quarrell. So had Alexander none now to stand in his way but Porus, to whom he sent a commandement, that he should attend him at the border of his Kingdome, there to doe him homage. But from Porus hee receiued this manly answere; That hee would satisfie him in his first demand, which was to attend him on his borders, and that well accompanied; but for any other acknowledgement hee was resolued to take counsell of his Sword. To be short, Alexander resolues to passe ouer the Riuer Hydaspes, and to find Porus at his owne home. Porus attends him on the farther banke with thirtie thousand foot, fourescore and ten Elephants, and three hundred armed Chariots, and a great troupe of Horse. If Darius had done the like on Tigris, Alexander had surely staid somewhat longer ere he had seene India. The Riuer was foure furlong broade, which makes halfe a mile, and withall deepe and swift. It had in it many Ilands, among which there was one well shadowed with wood, and of good capacitie. Alexander sent Ptolomie vp the Riuer with a great part of the Armie, shrowding the rest from the view of Porus: who by this deuice being drawne from his first incamping, sets himself 
downe opposite to Ptolomie, supposing that the whole Armie of Macedon meant to force their passage there. In the meane while Alexander recouers the farther shore without resistance. He orders his troups and aduanceth towards Porus, who at first rather beleeues that Abiasares his Confederate (but now the Confederate of fortune) had beene come ouer Hydaspes to his aide, than that Alexander had past it. But he finds it otherwise, and sends his Brother Hagis with foure thousand horse, and a hundred armed waggons to entertaine him. Each waggon had in it foure to fight, and two to guide it; but they were at this time of litle vse: for there had fallen so much raine, and thereby the fields were so moistned, as the horses could hardly trot. The Scythians and Dahans had the Vantguard, who so galled these Indians as they brake their reines, $\&$ other furniture, ouerturning the wagons $\&$ those in them. Perdiccas also gaue vpon the Indian horsemen, and the one $\&$ the other were forst to recoile. Porus moues forward with grosse of his Armie, that those of his Vantguard scattered might recouer his Reare: Alexander being followed with Ephestion, Ptolomie, and Perdiccas, tooke on him to charge the Indian horse-men on the left wing, commanding Cenus or Cenon to inuade the right; Antigonus and Leonatus, hee directed to breake vpon Porus his battaile of foote, strengthened with Elephants, Porus himselfe being carried vpon one of them of the greatest stature. By these beasts the Macedonian foot were most offended; but the Archers and Darters being well guarded with the long and strong Pikes of the Macedons, so galled them, as being inraged, they turned head and ranne ouer the foote that followed them: In the end; and after a long and doubtfull fight, by the aduantage of weapon, and by the courage and skilfulnesse of the Macedonian Captaines, the victorie fell to Alexander, who also farre exceeded Porus in number: for besides the Macedonians and other Easterne and Northern Nations, Porus was assailed by his owne Confederate and Countrie people. Yet for his owne person he neuer gaue ground otherwise than with his sword towards his enemies, till being weakened with many wounds, and abandoned by his Armie, he became a prisoner to the Conqueror, from whom againe he receiued his estate with a great enlargement. 
$\$ 2 \mathrm{I}$. How Alexander finished his expedition, and returned out of India.

I forbeare to trouble my selfe and others with a friuolous discourse of Serpents, Apes, and Peacocks, which the Macedonians found in these their trauailes: or of those pettie Wars which Alexander made betweene the ouerthrow of Porus, and his sailing downe the Riuer of Indus. The descriptions of places about the head and branches thereof are better knowne vnto vs in this Age, by meanes of our late Nauigations into those parts, than they were in any former times. The magnificence and riches of those Kings we could in no sort be perswaded to beleeue, till our owne experience had taught vs, that there were many stranger thinges in the World, than are to bee seene betweene London and Stanes.

Our great traueller Mandeuile who died in the yeare I 372 . and had seene so much of the World, and of the East India, wee accompted the greatest fabler of the World; yet had he an other reputation among other Nations, as well able to judge as we. Witnesse the Monument made of him in the Conuent of the Friers Guillimins in Liege, where the religious of that place keepe some thinges of his, Comme pour honorable memoire de son Excellence; For an honorable memorie of his Excellencie, saith Guichardine.

The Countries towards the Springs of Indus, and where those many Riuers of Hydaspes, Zaradris, Acesines, and the rest, fall into the maine streame, are now possest by the great Mogor, the ninth from Tamberlane, who commands all that tract betweene Persia and Indus towards the West, as also a great extent of Countrie towards Ganges. In the mouth of Indus, the Ascension, a ship of London, suffered shipwrack in the yeare I609. and some of the companie trauailed ouer Land till they came to Agra, the same great Citie (as I take it) which our later Cosmographers call Nagra, being named of old Dionysopolis.

Phylostratus in the life of Apollonius Tyancus, speaking of the expedition of Bacchus and Hercules into the East India, tells vs that those two great Captaines (whom Alexander sought by all meanes to out-fame) when they indeuored to subject vnto them the Oxydrace; a people inhabiting be- 
tweene the Riuers of Hyphasis and Ganges, they were beaten from the assault of their Cities with thunder and lightnings. This may well be vnderstood by the great Ordinance that those people had then in vse. For it is now certainely knowne, that the great Kings of the vttermost East, haue had the vse of the Cannon, many hundreds of yeares since, and euen since their first ciuilitie and greatnesse, which was long before Alexanders time. But Alexander pierst not so farre into the East. It sufficed, that hauing alreadie ouer-wearied his Armie hee discouered the rest of India by fame. The Indian Kings whom he had subdued, informed him, that a Prince called Aggramenes, who commanded many Nations beyond the Riuer of Ganges, was the powerfullest King of all those Regions: and that he was able to bring into the field two hundred thousand Foot, three thousand Elephants, twentie thousand Horse, and two thousand armed Chariots. With this report, though Alexander were more inflamed than euer to proceede in this discouerie and conquest, yet all the art he had could not perswade the Souldiers to wander ouer those great desarts beyond Indus and Ganges, more terrible vnto them than the greatest Armie that the East could gather. Yet at the last contented they were, after many perswasiue Orations, to follow him towards the South, to discouer such part of the Ocean Sea, as was nearer at hand, whereunto the Riuer of Indus was their infallible guide. Alexander seeing that it would bee no otherwise, deuised a prettie trick, where-with hee hoped to beguile posteritie, and make himselfe seeme greater than he was. He enlarged his Campe, made greater trenches, greater cabbines for the Souldiers, greater Horse-stalls, and higher mangers than his Horses could feede in. He caused all furniture of Men and Horses to bee made larger than would serue for vse; and scattered these Armours and Bridles about his Campe, to be kept as reliques, and wondered at by the sauages. Proportionable to these he raised vp twelue great Altars to be the monument of his journies end. This was a readie way to encrease the fame of his bignesse; to his greatnesse it could adde nothing saue a suspition that it was lesse than is thought, seeing he stroue so earnestly to make it thought more than it was.

This done, he returned againe to the banke of Acesines, SWR L 2 
and there determined to set vp his fleet where Acesines and Hydaspis incounter, where to testifie by a surer monument, how farre he had past towards the East, built by those Riuers two Cities: the one hee called Nicea, and the other Bucephalon, after the name of his beloued Horse Bucephalus. Here againe hee receiued a fourth supply of sixe thousand Thracian Horse-men, seuen thousand Foot, and from his Lieutenant at Babylon fiue and twentie thousand Armours, garnished with siluer and gold which hee distributed among his Souldiers. About these Riuers he wanne many Townes, and committed great slaughter on those that resisted; It is then written of him, that assaulting a Citie of the Oxidracans, he lept from the top of the wall into it, and fought, I know not how long, against all the Inhabitants; tales like those of Beuis of Southampton, friuolous and incredible. Finally, hee past downe the Riuer with his fleet, at which time also the newes came vnto him of a rebellion in Bactria, and then of the arriuall of an hundred Embassadours from a King of India, who submitted himselfe vnto him. He feasted these Embassadours vpon a hundred beds of gold, with all the sumptuositie that could be deuised, who soone after their dispatch returned againe with a present of three hundred Horse, one hundred and thirtie Wagons, and to each foure Horses, a thousand Targets, with many other things rare and rich.

Their entertainements ended, he sailes towards the South, passeth through many obscure Nations, which did all yeeld vnto him either quietly or compelled by force: among these he builded another Alexandria. Of many places which he tooke in this passage, Samus was one, the Inhabitans whereof fought against him with poisoned Swords, with one of which Ptolomie (afterward King of $E g y p t$ ) was wounded and cured by an hearbe which Alexander dreamt that he had seene in the mouth of a Serpent.

When he came neare the out-let of Indus (being ignorant of the tides of the Sea) his Gallies as they were on a suddaine shuffled one vpon an other by the Floud, so on the Ebbe they were left on the drie ground, and on the sandie bankes of the Riuer, wherewith the Macedonians were much amazed, but after hee had a few daies obserued well the course of the 
Sea, he past out of the riuers mouth some few miles, and after Sacrifices offered to Neptune returned: and the better to informe himselfe, hee sent Nearchus and Onesicritus, to discouer the coast towards the mouth of Euphrates. Arrianus in the beginning of his sixt Booke hath written this passage downe the Riuer of Indus at length, with the manner of the Vessells, in which hee transported his Armie, the Commanders that were vsed therein, and other the maruailous prouisions made.

Neare the out-lets of this Riuer hee spent some part of the Winter, and in eighteene daies march from thence recouered Gedrosia, in which passage his Armie suffered such miserie for want of foode, that of a hundred and twentie thousand foot, and twelue thousand horse, which hee carried into India, not the fourth part returned aliue.

\section{\$22. Of Alexanders Riot, Crueltie, and death.}

From Gedrosia Alexander led his Armie into Carmania, and so drawing neare to Persia, hee gaue himselfe wholly to feasting and drinking, imitating the triumphs of Bacchus. And though this Swinish vice bee hatefull enough in it selfe, yet it alwaies inflamed this King to Crueltie. For (saith Curtius) the Hang-man followed the feast, for Aspastes one of his Prouinciall Gouernours he commanded to be slaine, so as neither did the excesse of voluptuousnesse qualifie his crueltie, nor his crueltie hinder in ought his voluptuousnesse.

While he refreshed his Armie in these parts, a new supply of fiue thousand foote and a thousand horse, was brought him by Cleander, and his fellowes, that had been imploied in the killing of Parmenio. Against these Murderers great complaint was made, by the Deputies of the Prouinces in which they had commanded; and their offences were so outragious, as Alexander was perswaded, that, had they not altogether despaired of his returne out of India, they durst not haue committed them. All men were glad of the occasion, remembring the vertue of him whom they had slaughtered. The end was, That Cleander and the other chiefe, with sixe hundred Souldiers by them imploied, were deliuered ouer 
to the Hang-man: euery one rejoycing that the Ire of the King was at last executed on the ministers of his Ire.

Nearchus and Onesicritus were now returned from the coast, and made report of an Iland rich in gold, and of other strange thinges; whereupon they were commanded to make some farther discouerie: which done, that they should enter the mouth of Euphrates, and finde the King at Babylon.

As he drew neare to Babylon he visited the Sepulchre of Cyrus in Pasargada, now called Chelquera: where he was presented with many rich gifts by Orsines, one of the Princes of Persia, of the race of Cyrus. But because Bagoas, an Eunuch in especiall fauour with the King, was neglected, he not only practised certaine loose fellowes to witnesse against Orsines, that he had robbed Cyrus Tomb, for which he was condemned to die; but hee assisted the Hang-man with his owne handes in tormenting him. At which time also Alexander caused Phradates to be slaine, suspecting his greatnesse. Caperat (saith Curtivs) esse praceps ad representanda supplicia, item ad deteriora credenda; He beganne headlongly to shed bloud, and to beleeue false reports. It is true, that he tooke a way to make all men wearie of his gouernement, seeing crueltie is more fearefull than all the aduentures that can be made against it.

At this time it is said that Calanus the Philosopher burnt himselfe, when hee had liued threescore and thirteene yeares. Whether herein he followed the custome of his Countrie, being an Indian, Or sought to preuent the griefe and incommoditie of elder age, it is vncertaine: but in this the Historians agree, that fore-seeing and fore-shewing Alexanders death, he promised to meete him shortly after at Babylon.

From Pasargada hee came to Susa, where hee married Statira, Darius his eldest Daughter, giuing her yonger sister to his beloued Ephestion, and fourescore other Persian Ladies to his Captaines. There were sixe thousand guests inuited to the feast, to each of which he gaue a cup of gold. Here there came vnto him three thousand yong souldiers out of his conquered Prouinces, whereat the Macedonians greatly murmured. Harpalus, his Treasurer in Babylon hauing lauishly consumed the monies in his keeping, got him going 
with fiue thousand talents, and sixe thousand hired Souldiers, but he was rejected in Greece, and there slaine. Alexander greatly rejoyced at the fidelitie of the Greekes, whom Harpalus with these forces and treasures could not stirre: yet hee sent commandement that they should againe receiue their banished men, whereunto (fearefull of his indignation) all submitted themselues, (except the Athenians) though they resolued that it was a manifest preparation towards their bondage. After this there followed a maruailous discontentment in his Armie, because he had resolued to send into Macedon all those old Souldiers which could no longer indure the trauell of Warre, and to keepe the rest in Asia. $\mathrm{He}$ vsed many Orations to satisfie them, but it was in vaine during the tempest of their furie. But afterward, as Whales are drawne to the Land with a twine threed, when they haue tumbled a while, so are the vnconsiderate multitude easily conducted when their first passions are evaporate. With such as were licenced to depart, he sent Craterus, to whom he gaue the Lieutenantship of Macedon, Thessalie, and Thrace, which Antipater had held from his first departure out of Europe, who had beaten the rebellious Greekes in his absence, discharged the trust committed vnto him with great fidelitie, and sent him so many strong supplies into Asia from time to time. Certainely, if Alexander had not taken counsell of his cups, hee would haue cast some better colour on this alteration, and giuen Antipater a stronger reason for his remoue, than to haue imploied him in the conduction of a new supply to be brought him to Babylon, the warre being now at an end. For Antipater saw nothing in this remoue, but the Kings disposition to send him after $P$ armenio, and the rest. With this Antipater, the King, notwithstanding his great courage, had no great appetite to grapple: Princes, though jealous, doe not stand in doubt of euery man ill-affected though valiant; but there is a kinde of Kingly courage, compounded of hardinesse and vnderstanding, which is many times so fearefull vnto them, as they take leaue both of Law and Religion, to free themselues thereof.

After hee had sent for Antipater, hee made a journie into Media to settle thinges there; where Ephestion, whom he fauoured most of all men, dies. The King according to the 
greatnesse of his loue, laments his losse; hangs his Phisition; and bestowes vpon his Monument twelue thousand talents: After which hee returnes to Babylon. Thither Antipater came not, but sent; and not to excuse himselfe, but to free himselfe. For if we beleeue Curtius (whom Plutarch and others gaine-say) Antipater by his Sonnes, Cassander, Philip, and Iolla, who waited on Alexanders cup, gaue him poison, Thessalus (who was of the conspiracie) hauing inuited him to a drinking feast of purpose. For after he had taken a carouse in Hercules his cup, a draught of drinke stronger than Hercules himselfe, he quitted the World within a few daies.

Certainely the Princes of the World haue seldome found good by making their ministers ouer-great, and thereby suspitious to themselues. For he that doth not acknowledge fidelitie to bee a debt, but is perswaded that Kings ought to purchase it from their Vassalls, will neuer please himselfe with the price giuen. The only restoratiue, indeed, that strengthens it, is the goodnesse and vertue of the Prince, and his liberalitie makes it more diligent; so as proportion and distance be obserued. It may be that Antipater hauing commanded two or three Kingdomes twelue yeares, knew not now how to play any other part; no more than Ceesar did, after he had so long a time gouerned the Gaules, where he vtterly forgat the art of obedience. A most cruell and vngratefull traitor Antipater was, if Curtius doe not belie him: For though hee feared some ill measure vpon his remoue (the Tragedies of Parmenio, Clytus, and Callisthenes, hauing beene so lately acted) yet he knew nothing to the contrarie, but that the King had resolued to haue giuen him some other great gouernement in Asia: the old Souldiers thence returned, hauing perchance desired to be gouerned by Craterus, whom they had followed in all the former Warre.

\section{\$23. Of Alexanders Person and qualities.}

Howsoeuer it were, Alexanders former cruelties cannot bee excused, no more than his vanitie to be esteemed the sonne 
of Iupiter, with his excessiue delight in drinke and drunkennesse, which others make the cause of his feuer and death. In that hee lamented his want of enterprising, and grieued to consider what hee should doe when hee had conquered the World, Augustus Cesar found just cause to deride him, as if the well gouerning of so many Nations and Kingdomes, as he had alreadie conquered, could not haue offered him matter more than aboundant, to busie his braines withall. That he was both learned and a louer of learning, it cannot be doubted. Sr Francis Bacon, in his first booke of the aduancement of learning, hath proued it sufficiently. His liberalitie I know not how to praise, because it exceeded proportion. It is said, That when he gaue a whole Citie to one of his Seruants, $\mathrm{He}$, to whom it was giuen, did out of modestie refuse it, as disproportionable to his fortune: to whom Alexander replied, That hee did not enquire what became him to accept, but the King to giue: of which Seneca; ... It seemes a braue and royall speech, whereas indeede it is very foolish. For nothing simply considered by it selfe beseemes a man. We must regard what, to whom, when, why, where, and the like; without which considerations no act can be approued. Let honours bee proportioned vnto the persons: for whereas vertue is euer limited by measure, the excesse is as faultie as the defect.

For his Person, it is very apparant, That he was as valiant as any man, a disposition taken by it selfe, not much to be admired; For I am resolued that hee had ten thousand in his Armie as daring as himselfe. Surely, if aduenturous natures were to be commended simply, wee should confound that vertue with the hardinesse of Theeues, Ruffians, and mastife Dogges. For certainely it is no way praise-worthie but in daring good thinges, and in the performance of those lawfull enterprises, in which we are imploied for the seruice of our Kings and Common-weales.

If we compare this great Conquerour with other Troublers of the World, who haue bought their glorie with so great destruction, and effusion of bloud, I thinke him farre inferiour to Cesar, and many other that liued after him, seeing hee neuer vndertooke any warlike Nation, the naked Scythians excepted, nor was euer encountred with any 
Armie of which he had not a most mastring aduantage, both of weapons and of Commanders, euery one of his Fathers old Captaines by farre exceeding the best of his Enemies. But it seemeth, Fortune and Destinies (if we may vse those termes) had found out and prepared for him, without any care of his owne, both heapes of Men, that willingly offered their necks to the yoke, and Kingdomes that inuited and called in their owne Conquerours. For conclusion, wee will agree with Seneca, who speaking of Philip the Father, and Alexander the Sonne, giues this judgement of them. Quod non minores fuere pestes mortalium quàm inundatio, qua planum omne perfusum est, quàm conflagratio qua magna pars animantium exaruit; That they were no lesse plagues to mankinde, than an ouer-flow of waters, drowning all the leuell; or some burning droughth, whereby a great part of liuing creatures is scorched vp.

\section{Ch. III. The raigne of Aridævs}

\section{Ch. IV. Of the great Lordship} which Antigonvs got in Asia

\section{Ch. V. Of the great ciuill Warre betweene Alexanders Captaines...}

Ch. VI. Of the warres betweene... Alexanders Princes... 